\title{
Universiteit
}

The Netherlands

\section{Social motives and strategic misrepresentation in social decision} making.

Steinel, W.; Dreu, C.K.W. de

\section{Citation}

Steinel, W., \& Dreu, C. K. W. de. (2004). Social motives and strategic misrepresentation in social decision making. Journal Of Personality And Social Psychology, 86(3), 419-434. doi:10.1037/0022-3514.86.3.419

Version: $\quad$ Not Applicable (or Unknown)

License: $\quad$ Leiden University Non-exclusive license

Downloaded from: https://hdl.handle.net/1887/14958

Note: To cite this publication please use the final published version (if applicable). 
Running Head: LYING AND DECEPTION

Social Motives and Strategic Misrepresentation in Social Decision Making

Wolfgang Steinel and Carsten K. W. De Dreu

University of Amsterdam

\section{Important note:}

This is the author's final draft (dated July 7, 2003) of "Social Motives and Strategic Misrepresentation in Social Decision Making,” by Steinel, Wolfgang; De Dreu, Carsten K.

W., from Journal of Personality \& Social Psychology. 2004 Mar Vol 86(3) 419-434; (c) 2004 APA, all rights reserved.

This article may not exactly replicate the final version published in the Journal of Personality and Social Psychology (http://www.apa.org/journals/psp/). It is not the copy of record.

Wolfgang Steinel is now at Leiden University, P. O. Box 9555, 2300 RB Leiden, The Netherlands. Electronic mail can be sent to wsteinel@fsw.leidenuniv.nl. 


\begin{abstract}
In 4 experiments we examined lying and deception as a function of beliefs about other's cooperative or competitive motivation, and of own social value orientation. In a newly developed Information Provision Game, individuals gave information about payoffs that provided the basis for an interdependent other to make a decision affecting both parties' outcomes. Results showed that withholding information was associated with fear of being exploited, greed, and punitive sentiment, and that giving inaccurate information was associated with greed. Further, individuals gave less accurate and more inaccurate information when the other was competitive rather than cooperative, especially when they had a pro-social rather than selfish value orientation. Finally, individuals facing a competitive other misrepresented the decision problem as one of compatible rather than opposed interests, a tendency indicative of a "if you can't beat them, join them" strategy.
\end{abstract}


Social Motives and Strategic Misrepresentation in Social Decision Making

In his classic novel "The Adventures of Tom Sawyer," Mark Twain tells the story of Tom Sawyer, who is painting Aunt Polly's fence when Ben Rogers walks by, eating an apple and heading for the river to go for a swim. It is a beautiful day and when Ben asks why Tom is painting the fence rather than going for a swim, Tom decides not to answer truthfully-instead he tells Ben that he is actually enjoying himself and that painting the fence is an interesting and gratifying activity. Because Tom is so convincing, he actually raises Ben's desire to engage in whitewashing and, after some negotiation, Tom hands over the brush to Ben, and lies down in the shadow eating the rest of Ben's apple.

By suggesting he loves whitewashing, and thus misrepresenting his true preferences, Tom Sawyer manipulates Ben Rogers to make a decision that is favorable to Tom. And although few of us may be as cunning and convincing as Tom Sawyer, we often find ourselves in situations where we can influence others by manipulating information and misrepresenting our true preferences and priorities. Tobacco companies misrepresent the addictive properties of nicotine (Tenbrunsel, 1998). Car owners deliberately conceal technical problems when trying to sell their car (Schweitzer \& Croson, 1999). When negotiating a divorce, a husband may misrepresent the importance of having child custody to induce his spouse to concede on alimentation costs (O’Connor \& Carnevale, 1997).

Although lying and deception have been of interest to the social sciences for many decades, this research has mainly focused on animal and human ability to distinguish cheaters from non-cheaters (e.g., Cosmides \& Tooby, 1992; DePaulo, 1992). Far less research has been concerned with what Tom Sawyer was doing--the active misrepresentation of values, preferences and priorities. Extending interdependence theory (Kelley \& Thibaut, 1978; Rusbult \& Van Lange, 1996, 2003), and goal expectation theory (Pruitt \& Kimmel, 1977), we study the influence of one's counterpart's cooperative or competitive motivation and one's 
own pro-social or selfish value orientation on the tendency to provide accurate or inaccurate information, answering such basic questions as "When and why are individuals likely to deceive their counterparts?" and "How do they fine-tune the provision of accurate or inaccurate information to influence their counterpart's decision making?"

\section{Lying and Deception in Social Interaction}

Misrepresentation, lying, and deception have all been subject of considerable research in psychology. Social psychologists have focused on the individual's ability to detect lying and deception by others (e.g., DePaulo, Lanier, \& Davis, 1983; DePaulo, Stone, \& Lassiter, 1985; Riggio \& Friedman, 1983; Zuckerman, Koestner, \& Alton, 1984; see also DePaulo et al., 2003). Even when people try hard to suppress and misrepresent their true feelings and thoughts, they usually are not very successful (e.g., DePaulo, 1992; Ekman \& Friesen, 1982; Ekman, Friesen, \& O’Sullivan, 1988; Zuckerman, Lipets, Koivumaki, \& Rosenthal, 1975, Vrij, Edward, \& Bull, 2001b). Lie detection has also received much attention in forensic and applied psychology. For instance, research has looked at the effectiveness of technical devices such as the polygraph to tell truth tellers from liars (e.g., Bashore \& Rapp, 1993).

Relatively few studies have addressed the conditions that foster or inhibit people's tendency to be honest and accurate, or dishonest and inaccurate. Some studies have examined the role of Machiavellianism (Exline, Thibaut, Hickey, \& Gumpert, 1970; O'Hair, Cody, \& McLaughlin, 1981), but these studies provided rather mixed results (Vrij, 2001). Most insight in the conditions predicting lying and deception comes from research on conflict and negotiation. In conflict and negotiation, individuals experience mixed-motive interdependence. They have cooperative incentives to work together with the other party to increase joint gain, and competitive incentives to work against the other party to increase personal gain (Schelling, 1960). The cooperative incentive makes the situation particularly conducive to the exchange of honest and accurate information, because doing so successfully 
fosters high joint gain. The competitive incentive makes the situation particularly conducive to the use of misrepresentation and deception, because doing so successfully fosters one's immediate, personal self-interest (Triandis et al., 2001). Thus individuals in mixed motive interdependence find themselves in what has been called the "information dilemma"--should they provide accurate information to achieve high collective outcomes, or strategically misrepresent their preferences to foster good personal outcomes (Kelley \& Thibaut, 1978; Murnighan, Babcock, Thompson, \& Pillutla, 1999)?

\section{Experiment 1}

Individuals in an information dilemma engage in a variety of deceitful activities (e.g., Kelley, 1966; for a review, see Lewicki, 1983). Deception increases when parties know the opponent lacks information (Boles, Croson, \& Murnighan, 2000), or when the stakes are higher (Tenbrunsel, 1998). Also, lying and deception are more likely when negotiators have experience with the task at hand (Murnighan et al., 1999), when they face a stranger rather than a friend (Schweitzer \& Croson, 1999), and when they aim to maximize personal rather than joint gains (O'Connor \& Carnevale, 1997). This research thus suggests that people deceive more when there is greater need to serve one's own interests, or more opportunity to do so, or both.

\section{Perception of Other's Competitiveness}

Sometimes, individuals assume that their counterpart is competitive and "out to get them," and sometimes that their counterpart other has cooperative intent and can be trusted (e.g., Kelley \& Stahelski, 1970). Burnham, McCabe, and Smith (2000) found that others described as "partner" elicit more cooperation than others described as "opponent." Other research showed that people see others as cooperative rather than competitive when they have a history of cooperative rather than competitive exchanges (e.g., Lindskold \& Han, 1988), when they expect to work together in the future (e.g., Ben-Yoav \& Pruitt, 1984), or when the 
other is a friend rather than a stranger (Fry, Firestone, \& Williams, 1983). Also, individuals differ in their propensity to trust others (Parks, Henager, \& Scamahorn, 1996), and when individuals themselves are inclined to be cooperative, they tend to assume others are cooperative rather than competitive as well (e.g., Iedema \& Poppe, 1995). In developing their goal expectation theory, Pruitt and Kimmel (1977) reviewed twenty years of research and concluded that perceiving the other as cooperative rather than competitive is a key factor in predicting cooperative choices in prisoner's dilemmas, social dilemmas and negotiation settings (see also Komorita \& Parks, 1995; Pruitt, 1998).

Work on lying and deception has ignored that individuals assume others to be competitive or cooperative, but the above research and theory suggest this to influence the tendency to be accurate or to deceive. First, facing a competitive rather than cooperative other reduces the inhibition to engage in unethical behavior (Rubin, Pruitt, \& Kim, 1994). Facing a competitive other may also make greed--the desire to get high personal outcomes--more salient, which in turn leads to more lying and deception aimed at doing well for oneself, perhaps even at other's expense. Finally, facing a competitive other increases the fear of being exploited (Pruitt \& Kimmel, 1977). Thus, we predict that facing a competitive rather than cooperative other reduces the tendency to be accurate and increases misrepresentation (Hypothesis 1).

Hypothesis 1 is about the amount of deceit, and it extends interdependence theory (Kelley \& Thibaut, 1978; Rusbult \& Van Lange, 1996, 2003) and goal expectation theory (Pruitt \& Kimmel, 1977) to the domain of lying and deception. However, neither this hypothesis, nor the theories and research preceding it, specifies the direction of deceit. Therefore, the question remains how people misrepresent information when facing a competitive other. Non-cooperative tendencies may be reflected in withholding information, or in focused misrepresentation explicitly aimed at misleading the counterpart about the 
structure of the decision-making task. Thus, the specific direction of deceit in case of a competitive counterpart is less straightforward than it may appear at first sight.

When one's own interests are opposite to those of a competitive other, one serves one's own interests best by suggesting that one gets negative outcomes when the other gets zero, and more positive outcomes when the other gets positive outcomes. To illustrate this, imagine a situation in which a competitive counterpart has to choose between $\mathrm{X}$ and $\mathrm{Y}$. $\mathrm{X}$ gives him or her 0 , and $\mathrm{Y}$ gives him or her 5. Unknowingly to the other, $\mathrm{X}$ gives you 5, and $\mathrm{Y}$ gives you 0 . If you are honest about your outcomes, your competitive counterpart will be tempted to choose $\mathrm{Y}$ because this maximizes his or her relative gain (i.e., 5 for him or her, and zero for you). To prevent this bad result, you could mislead the other and inform him or her that $\mathrm{X}$ gives you a negative outcome (e.g., -10) and that $\mathrm{Y}$ gives you greater outcomes than him or her (e.g., +10). Doing so may tempt the competitive counterpart to choose $\mathrm{X}$ instead of $\mathrm{Y}$, because he or she believes that $\mathrm{X}$ maximizes relative gain (i.e., 0 for him or her, and -10 for you), whereas Y maximizes relative loss (i.e., 5 for him or her, and 10 for you). If such misrepresentation of your outcomes is successful, it would give you great outcomes (recall that although the other thinks otherwise, $\mathrm{X}$ gives him or her 0 , and you 5).

This numerical example reflects what Tom Sawyer was doing when he persuaded Ben that giving up whitewashing would be like punishment to him, thereby tempting Ben to give Tom his apple to be able to take over whitewashing. Thus, it can be predicted that with competitive but not with cooperative others, individuals will misrepresent the situation in such a way that own outcomes appear negative when the other gets zero, and to exceed other's positive outcomes (Hypothesis 2).

\section{Overview of the Experiment}

In Experiment 1, participants played an Information Provision Game developed for this study. In this game, participants expect their counterpart to make a decision that yields 
outcomes to him or herself and to the participant. The game is set up so that the participant's and the decision maker's outcomes are negatively correlated--there are opposed interests. However, participants are told that the decision maker has incomplete information and is only aware of the consequences of his or her decision to his or her own outcomes, and not of the consequences of his or her decision to the participant's outcomes (i.e., the decision maker does not know that the situation involves opposed interests). In contrast, the participant is given full information about own outcomes, and about the decision maker's outcomes, and thus knows that own and other's interests are opposed. Prior to the decision-making, participants get the opportunity to inform the decision maker about the consequences for the participant's outcomes. Participants can accurately present the situation as involving opposed interests, they can withhold information, they can inaccurately present the situation as predicted in Hypothesis 2, or anything in between. Thus the Information Provision Game allows one to assess (a) the amount of accurate and inaccurate information participants give, and (b) the direction of deceit--the way participants represent the decision situation to their interdependent other.

The numerical example we gave when developing Hypothesis 2 involved a zero-sum situation--other's gain mirrors own loss and vice versa. Not all situations that involve opposing interests are zero-sum; when one party's gain exceeds the other party's loss, the situation is called variable-sum (Schelling, 1960). Participants in both the zero-sum and the variable-sum situation have full information--they know about their own and their counterpart's outcomes. Often, however, participants only have incomplete information; they know their own outcomes but have no insight in other's outcomes (Pruitt, 1998). In these incomplete information situations, people are likely to make a so-called fixed-pie assumption-they assume the situation is zero-sum, and their behavior reflects this assumption (Thompson \& Hastie, 1990; Schelling, 1960). 
Some prior work on deceit used zero-sum tasks (e.g., Boles et al., 2000), some used variable-sum tasks (e.g., O’Connor \& Carnevale, 1997), and some used incomplete information tasks (e.g., Schweitzer \& Croson, 1999). No previous work on the amount of deceit examined deceit as a function of task structure. Furthermore, because we know little about the direction of deceit, and because the precise structure of the situation may influence whether and how people (mis)represent the situation to their uninformed counterpart, we felt it desirable to examine the amount and direction of deceit in across zero-sum, variable-sum, and incomplete information tasks. In one condition of Experiment 1, participants engaged in a zero-sum task, in a second condition, they engaged in a variable-sum task, and in a third condition (the incomplete-information condition) they were presented with their own outcomes only (see the Method section for more detail). We had no a priori hypotheses about the influence of task structure. The variable was included to examine the generality of findings in different versions of the newly developed Information Provision Game.

The decision maker was depicted as either a cooperative or a competitive person (we also included a control condition in which no information about the decision maker was given). According to Hypothesis 1, facing as competitive rather than cooperative other reduces the amount of accurate information provided and increases the amount of inaccurate information given. According to Hypothesis 2, with competitive but not with cooperative others, individuals will misrepresent the situation in such a way that own outcomes appear negative when the other gets zero, and to exceed other's positive outcomes.

\section{Method}

Participants and design. Two hundred and fourteen students at the University of Amsterdam (136 female and 78 male) were randomly assigned to the conditions of a 3 (other's motivation: cooperative, competitive, unknown) x 3 (task structure: variable-sum, zero-sum, incomplete information) between-participants factorial design. Dependent variables 
were the information participants gave about their payoffs, perceptions of the other, and selfreported strategies. Participants received 20 Dutch guilders (approx. US\$ 8) for participation.

Procedure and independent variables. Upon arrival in the laboratory, participants were seated in cubicles equipped with a computer, a pen and several blank sheets of paper. To manipulate other's cooperative or competitive goals (see also below), participants were asked to complete a "collaboration skills test as part of a large-scale test-development project that is not related to the other tasks in this experiment." The test contained twenty items dealing with cooperation in daily life (e.g., "In the bus, I stand up and leave my seat for older people"; "I enjoy working with other people"; "Winning is everything"; "I like situations in which I can compete with others"). Participants indicated their agreement on five-point scales $(1=$ completely disagree, to $5=$ completely agree). Although there is no information about the validity of the scale, and thus it cannot be used to classify participants in terms of their own social motivation (but see Experiment 3 and 4), previous research has shown the scale has high face validity and is useful for providing credible false feedback about another person's motives (De Dreu \& Van Kleef, in press).

Upon completion of the "collaboration skills test," the experimenter collected the materials and participants started with a new task on the computer. On their computer screens, participants read the instructions of a decision game that involved two players who would interact via the computer network. Participants were told that they would never find out with whom they played, and roles (player 1 or player 2) would be determined at random. In fact, each participant was placed in the role of information provider (player 1).

The purpose of the decision game was to determine an outcome concerning two issues, A and B. On both issues, one out of three levels, x, y, or z, had to be chosen. Player 2 (heretofore decision-maker) would determine for both the issues A and B which level (x, y, or z) would be chosen, and, as such, would determine both his or her own outcomes as well as 
the outcomes of Player 1 (heretofore information-provider). Participants read that the decision-maker would receive information about his or her own payoffs, but would never receive objective information about the information-provider's payoffs. Thus, the decision maker had incomplete information. The information provider would receive information about his or her payoffs and also about the decision-maker's payoffs (except in one condition, see below).

The information provider would start the game by sending a message to the decision maker with information about the outcomes he or she would receive for each of the possible decision options the decision maker could choose from. The decision maker would then be asked to make a decision determining both his or her own outcomes and the information provider's outcomes. It was emphasized that decisions would results in a number of points, and that at the end of the experiment points would be converted into lottery tickets. The more points gained, the more lottery tickets one would get and, hence, the greater one's chance of winning a cash prize of 50 Dutch guilders (approx. US\$20).

Participants received their payoff schedules and detailed explanation. A quiz ensured that the instructions were understood. Table 1 shows the tasks used in this experiment. As can be seen, payoffs for the participant were identical in all three tasks. On issue A, they could earn 6,3 , or 0 points on level $\mathrm{z}, \mathrm{y}$, or $\mathrm{x}$, respectively. Issue $\mathrm{B}$, analogously, paid 2,1 , or 0 points. The decision maker's payoffs differed, depending on experimental condition. Participants in the incomplete-information condition did not get information about the decision maker's payoffs. Participants in the zero-sum task condition were shown other's payoffs, which were the exact mirror image of their own. Finally, participants in the variablesum task condition learned that the decision maker would obtain on issue A as many as 2,1 , or 0 points on level $\mathrm{x}, \mathrm{y}$, or $\mathrm{z}$, respectively, and on issue $\mathrm{B}$ as many as 6,3 , or 0 points, respectively. Thus in the variable-sum task, issue A is most important to the information 
provider (player 1), whereas issue B is most important to the decision maker (player 2).

Different decisions thus produce different levels of joint outcome for both the decision maker and the information provider together. For example, when deciding on $(\mathrm{zA}, \mathrm{xB})$ both players would get 6 points, while deciding on (yA, yB) would result in only 4 points per player. The information that the participant was "player 1," the payoff schedule of "player 1," and, in the variable-sum and zero-sum condition, the payoff schedule of "player 2," remained visible on the screen (see Figure 1a).

We then manipulated the decision maker's motivation. Participants were told that we were interested in consequences of having versus not having information about the other player, and that the computer had randomly selected them but not their other player to receive some information about the other derived from the "collaboration skills" measure filled out at the beginning of the experiment. They received the test allegedly filled out by the other, with circled numbers on the rating scales for each item being manipulated such that the other appeared competitive, or cooperative. For example, participants in the cooperative-other condition saw that the other answered " 2 " on the item "in the bus I stand up for other people $(1=$ almost ever, to $5=$ never $)$; participants in the competitive-other condition saw that on this item the other answered "4" (see also De Dreu \& Van Kleef, in press). In the unknownother condition, participants received no information about the decision maker's test results.

We then repeated that the decision-maker had no information about the payoffs of the information-provider and would never get objective information. Participants were told that they would be in a position to provide information about their own payoffs to the decisionmaker. They could fill in their outcomes in an empty payoff schedule that would be sent to the decision maker. Participants were also told that they could claim anything they wanted, that is, they could give as much information as they wanted and were free to choose between giving accurate and inaccurate information. Participants were given empty payoff schedule 
with below 25 boxes containing the numbers from -12 to +12 , and a box containing a question mark. They were told that for each of the six cells in their payoff schedule they could select by mouse-click either a number between -12 and +12 , or click on the box with a question mark when they did not want to give any information about their points in that cell (see Figure 1a). The choice then appeared in the appropriate cell of the payoff schedule (see Figure 1b). After this choice was made for all six cells, participants could change their choices as often as they wanted. Only after they confirmed by clicking the "send" button, would their choices become definite. The payoff schedule with the values participants pretend to get (in cells $\mathrm{xA}, \mathrm{yA}, \mathrm{zA}, \mathrm{xB}, \mathrm{yB}$, and $\mathrm{zB}$ ) was then allegedly sent to the decision-maker. The reader can consult Figures $1 \mathrm{a}$ and $1 \mathrm{~b}$ for the computer screen the participant saw during the game, along with two hypothetical response screens, one filled out by a participant providing full and accurate information, and one filled out by a participant providing full but inaccurate information as predicted in Hypothesis 2.

Dependent measures. The numbers provided in each cell (i.e., the numbers participants claimed were the values of the cells $\mathrm{xA}, \mathrm{yA}, \mathrm{zA}, \mathrm{xB}, \mathrm{yB}$, and $\mathrm{zB}$ in their own payoff schedule) were used to create two related indices of information provision. We classified all information as accurate or inaccurate. Inaccurate means that the number a participant entered into a cell was higher or lower than their objective payoff in that cell. By counting the cells that contained accurate and inaccurate information, we calculated an amount of accurate information and an amount of inaccurate information. Both indices are discrete with a range of 0 to 6 , the sum of both indices equals the total amount of information given. As participants had to enter numbers or question marks into six cells of the payoff schedule, the number of cells in which they gave no information (question marks) equals six minus the amount of accurate information minus the amount of inaccurate information. After participants had sent the information, they were asked whether or not they had 
applied the following strategies: (1) "enter a high number into a cell to deter the other from choosing that cell," and (2) "enter a low number into a cell to make the other choose that cell." (We did not specify what cells we were referring to). We also asked whether participants had tried to mislead the other. To check the adequacy of the manipulation of other's cooperativeness or competitiveness, we asked participants to indicate whether the decision maker was a (1) cooperative, to (5) competitive person. Participants were then told the experiment was over, and they were paid and debriefed.

Results

Manipulation check, and perception of the other. A 3 (task structure: variable-sum, zero-sum, incomplete information) x 3 (other's motivation: cooperative, competitive, unknown) analysis of variance (ANOVA) on ratings of other's competitiveness only showed a significant main effect of other's motivation, $F(2,205)=71.13, p<.001$, indicated that the decision maker was seen as more competitive in the competitive-other condition $(M=4.18$, $S D=0.96)$ than in the cooperative-other condition $(M=2.01, S D=1.01)$. In the unknownother condition, ratings were close to the scale's midpoint $(M=2.91, S D=1.16)$. A Duncan test showed that all conditions differed significantly from each other $(p<.05)$.

Amount of accurate and inaccurate information. To test Hypothesis 1, we analyzed the amount of accurate and inaccurate information in a 3 (other's motivation) x 3 (task structure) x 2 (information: accurate or inaccurate) ANOVA with the last factor as a withinparticipants variable. A within-participants main effect for information showed that participants provided more inaccurate than accurate information $(M=2.91, S D=2.37$ vs. $M$ $=2.19, S D=2.28), F(1,205)=9.97, p<.002$. A significant interaction between information and other's motivation, $F(1,205)=22.18, p<.001$, qualified this main effect. Cell means are shown in Table 2. Participants gave more accurate information when the other was cooperative rather than competitive, with an unknown other in between, and gave more 
inaccurate information when the other was competitive rather than cooperative. This supports Hypothesis 1. No other effects were found.

Direction of deceit. To examine the direction of deceit, the information provided in each cell was submitted to a 3 (task structure) x 3 (other's motivation) x 2 (issue: A vs. B) x 3 (level: x vs. y vs. z) ANOVA with the last two variables as within-participants factors. Question marks were treated as missing values, which led to the exclusion of 71 participants. A main effect of issue, $F(1,134)=4.00, p<.05$, showed that participants correctly told the decision maker that they got more points on issue A than on issue $\mathrm{B}(M=2.36, S D=$ 2.39 vs. $M=1.98, S D=2.55)$. An interaction between issue and other's motivation, $F(2,134)$ $=4.60, p<.012$, shows that participants presented issue $\mathrm{A}$ as more valuable than issue $\mathrm{B}$ when they believed the other was cooperative. Trends suggest that they did so towards an unknown other, as well, whereas they presented issue A as less valuable than issue B towards a competitive opponent (cell means and paired-sample $t$ tests are shown in Table 3). The interaction between issue and level, $F(2,133)=3.91, p<.022$, shows that participants accurately stated that on level y and $\mathrm{z}$, issue A was more valuable to them $\left(M_{y}=2.75, S D=\right.$ $\left.3.16 ; M_{z}=2.29, S D=4.93\right)$ than issue $\mathrm{B}\left(M_{\mathrm{y}}=2.11, S D=3.22 ; t(142)=2.78, p<.01 ; M_{\mathrm{z}}=\right.$ $1.53, S D=3.77, t(142)=2.76, p<.01)$, and that on level $\mathrm{x}$ there was no difference in value between issue A and issue $\mathrm{B}\left(M_{\mathrm{x}}=2.04, S D=5.16\right.$, vs. $\left.M_{\mathrm{x}}=2.29, S D=4.86\right)$. This interaction effect thus mainly reflects the specific numbers given in the payoff matrices.

More importantly, results revealed a significant interaction between other's motivation and level, $F(4,268)=11.45, p<.001$, indicating that participants pretended to have different priorities within issues depending on other's motivation. Figure 2 shows that information given to a cooperative other (i.e., the pretended value) almost perfectly matches the given values of 0,2 , and 4 points at level $\mathrm{x}, \mathrm{y}$, and $\mathrm{z}$, respectively. Thus, with a cooperative other participants were quite honest. The information given to a competitor, 
however, decreases from $M_{\mathrm{x}}=5.73$ through $M_{\mathrm{y}}=2.03$ to $M_{\mathrm{z}}=-0.46$. Hence with a competitive other people misrepresent what truly are opposed interests as compatible interests. The information given to an unknown other is in between, showing intermediate levels of misrepresenting preferences and priorities within issues.

A significant three-way interaction between other's motivation, level, and issue, $F(4,268)=6.90, p<.01$, further qualified these findings. Participants with a cooperative other truthfully stated that they preferred level $\mathrm{z}$ to level y and level $\mathrm{x}$. They also truthfully said that they would get more points in cell zA than in cell zB $\left(M_{z A}=4.25\right.$ vs. $M_{z B}=2.17$, $t(52)=5.03, p<.001)$. Participants with a competitive other dishonestly pretended to prefer level $\mathrm{x}$ to level $\mathrm{y}$ and level $\mathrm{z}$. Additionally, they misled their counterpart by stating that issue A was of a higher value to them than issue $B$, and pretended to get equally high scores in cell $\mathrm{xA}$ and in cell $\mathrm{xB}\left(M_{x A}=5.83\right.$ vs. $\left.M_{x B}=5.63, t(40)<1, \mathrm{~ns}\right)$.

Although the direction of deceit in the above results is in line with Hypothesis 2, they do not tell us whether people indeed present outcomes as negative when the other gets zero, and as exceeding other's positive outcomes. We examined the number of participants who suggested they would get negative outcomes when the other gets zero (cells zA and zB of the payoff matrices shown in Table 1) as a function of other's motivation. We excluded participants in the incomplete-information task condition because they had no information about other's outcomes. Including them did not change the results.

For issue A, the analysis showed a significant effect, $\chi^{2}(2, N=144)=24.90, p<.001$. Fewer people in the cooperative-other condition (2 out of 51,4\%) and the other-unknown condition ( 5 out of $54,9 \%$ ) pretended to receive negative outcomes than in the competitiveother condition (13 out of 40,33\%). A similar pattern was found for issue $\mathrm{B}, \chi^{2}(2, N=144)=$ $6.91, p<.032$ : Fewer people in the cooperative-other condition (4 out of 50,8\%) and the other-unknown condition (4 out of 54,7\%) suggested they would receive negative outcomes 
than in the competitive-other condition ( 9 out of 40,23\%). We then examined the number of participants suggesting their outcomes exceeded those of the other (cells xA and xB of the payoff matrices shown in Table 1) as a function of other's motivation. For issue A, the analysis showed a significant effect, $\chi^{2}(2, N=144)=17.54, p<.001$. Fewer people in the cooperative-other condition (4 out of 50,8\%) and the other-unknown condition (11 out of 54, $20 \%$ ) suggested their outcomes would exceed those of their counterpart than in the competitive-other condition (18 out of $40,45 \%)$. We found a similar pattern for issue $\mathrm{B}, \chi^{2}(2$, $N=144)=17.25, p<.001:$ Fewer people in the cooperative-other condition ( 9 out of 50, $18 \%)$ and the unknown-other condition (14 out of 54, 26\%) suggested their outcomes would exceed those of their counterpart than in the competitive-other condition ( 26 out of $40,65 \%$ ).

All in all, these results support Hypothesis 2: Towards a competitive rather than cooperative or unknown counterpart, people are more likely to misrepresent their outcomes as negative when the other gets zero, and as exceeding other's positive outcomes.

Self-reported strategies. Consistent with the above results, $77 \%$ of the participants with a competitive other stated to have entered a high number to deter the other from choosing that cell. Only $20 \%$ of the participants with a cooperative other and $27 \%$ of those with an unknown other indicated to have applied this strategy, $\chi^{2}(2, N=214)=53.26, p<$ .001 . Likewise, $79 \%$ of the participants with a competitive other stated to have entered a low number to make the other choose that cell, whereas only $28 \%$ of the participants with a cooperative other indicated having used that strategy. Participants with an unknown other (42\%) were in between, $\chi^{2}(2, N=214)=35.67, p<.001$. Finally, almost all participants with a competitive other (97\%) as compared to less than half (47\%) of those with a cooperative one indicated that they had tried to mislead the other. The unknown-other condition (61\%) was in between, $\chi^{2}(2, N=214)=38.34, p<.001$. 


\section{Discussion}

As predicted in Hypothesis 1, individuals were less accurate and more inaccurate with a competitive rather than a cooperative other. Consistent with Hypothesis 2, individuals with a competitive other were also more likely to misrepresent their outcomes such that their outcome appeared negative when the other got zero, and exceeding other's positive outcome. This misrepresentation may be strategically wise, as it may tempt the competitive other to make a decision that is good rather than bad for one's own outcomes.

No effects for task structure were significant. This suggests that participants in the incomplete-information condition assumed their outcomes were negatively correlated with those of their counterpart (i.e., the values they provided did not differ from those given in the zero-sum, and the variable-sum conditions), which is consistent with negotiation studies showing that negotiators make a "fixed-pie assumption" (De Dreu, Koole, \& Steinel, 2000; Thompson \& Hastie, 1990). Although some authors have speculated that the fixed-pieassumption may be confined to negotiation settings (e.g., Pruitt, 1990), our results suggest that the fixed-pie assumption is made also in the type of situations studied here.

For current purposes it is important that task structure it had no effects on the amount of accurate or inaccurate information provided, or on the direction of deceit. Moreover, task structure did not interact with other's motivation. We conclude that task structure, alone or in combination with other's motivation, has no noticeable influence on deception and in the next experiments we, therefore, decided to focus on the zero-sum task.

\section{Experiment 2}

Although the results of Experiment 1 showed that individuals are especially likely to use deception when they face a competitive other, it remains unclear why. In general, noncooperative behavior is predominantly motivated by either fear of being exploited, by greed, or by both motives (Coombs, 1973). In the Information Provision Game, both fear and greed 
play a role as well, because the information participants present to the decision maker may lead him or her to make choices that benefit or harm the participant's outcome. Indeed, in Experiment 1, we observed more deception when the other was competitive rather than cooperative. This suggests that fear of being exploited is an important reason for misleading a competitive other. However, facing a competitive other in itself may elicit greed, and we need to examine empirically whether fear, greed, or both motivations explain the tendency to mislead a competitive other.

Research on motives underlying punishment suggests additional reasons underlying people's decision to engage in lying and deception. Carlsmith, Darley, and Robinson (2002) distinguished between deterrence and just deserts as motives for punishing harm-doers. Deterrence refers to the desire to prevent or reduce future crimes, and seems closely linked to fear of being exploited. Just deserts refer to the desire to pay back harm-doers for past crimes, and appears conceptually unrelated to both fear and greed. Just deserts motives seem to play a role in social decision-making. People who violate justice principles face sanctions even by those whose outcomes are not affected by these violations (Folger \& Skarlicki, 2001). People who have been deceived punish their counterpart even when this is costly to themselves (Boles et al., 2000). In the context of social dilemma research, Price, Cosmides and Tooby (2002) reasoned that for collective action to evolve, some mechanism must eliminate the advantage free riders have over contributors. They propose punitive sentiment as an anti-freerider device, which is "a desire that the target of the sentiment is harmed" (p. 206).

Taken together, three possible motivations may explain the high levels of deception observed in the case of a competitive other--fear, greed, and punitive sentiment. The goal of Experiment 2 was to examine which (combination of) motivation(s) explains the provision of accurate and inaccurate information to a competitive other. Following previous research on fear and greed (e.g., Bruins, Liebrand, \& Wilke, 1989; Van Lange, Liebrand, \& Kuhlman, 
1990), the presence or absence of fear and greed was manipulated by making the other's decision either consequential or not for one's own outcomes. When the other's decision is consequential for one's own outcomes, lying and deception may be motivated by a desire to mislead the other into making decisions that benefit oneself most, or a desire to mislead the other into making decisions that damage own outcomes the least. We used questionnaire items and mediation tests to examine whether effects are due to fear, greed, or both. Similarly, the presence of punitive sentiment was manipulated by making the other's decision either consequential or not for the other's outcomes--when the other's decision has no consequences for the other's outcomes, lying and deception can hardly be motivated by punitive sentiment. Put differently, if more lying and deception is observed when the other's decision is consequential for the other's outcomes, then lying and deception is likely to be due to punitive sentiment. Again we used questionnaire items and mediation tests to examine whether punitive sentiments indeed explain possible effects.

\section{Method}

Participants and design. Seventy-seven students at the University of Amsterdam $(n=$ 38 female and $n=39$ male) were randomly assigned to three experimental conditions--the other's decision is consequential to the participant's outcomes only, the other's decision is consequential to other's outcomes only, and the other's decision is consequential to both the participant's and the other's outcomes (note that the last condition is a replication condition of the task used in Experiment 1). Dependent variables were the provision of accurate and inaccurate information, self-reported fear, greed, and punitive sentiment, and manipulation checks. Participants received 15 Dutch guilders (approx. US\$ 6) for participation.

Procedure and independent variables. The procedure was the same as in the competitive-other condition in Experiment 1, with a few changes to manipulate whether or not the decision would be consequential to the outcomes of the participant and the decision 
maker. Whether the other's decision was consequential to the participant's and/or the other's outcome was manipulated independently by making each participant's own outcome and the alleged opponent's outcome either relevant or irrelevant to winning an attractive prize. We announced a lottery in which three participants would win a voucher of 50 Dutch guilders (about 26 US\$), with the chances of winning being either dependent on or independent of the outcome of the decision game. Depending on the experimental condition, participants were told that each point gained in the decision game was worth one lottery ticket to themselves and/or the decision maker, or that the participant and/or the decision maker would get a randomly determined number between 0 and 8 lottery tickets regardless of the outcome of the decision game. Thus, in some conditions, the outcome of the decision game had consequences for the participant's and/or the decision maker's chances of winning additional cash, while in other conditions it had no such consequences. We further emphasized that only the information providers would know how lottery tickets could be obtained and that this information was not shared with the decision maker. Thus, the decision maker was believed to be unaware of the fact that his or her decision would affect his or her (and the participant's) chances of winning additional cash.

In the other's decision is consequential only to self condition, participants were told that they would receive one lottery ticket for each point they would gain in the decision game, whereas the decision maker would receive a random number of tickets. In this condition, we assumed that both fear and greed would be relevant motives, while punitive sentiment would not. In the other's decision is consequential only to other condition, participants were told that they would get a randomly determined number of lottery tickets, whereas the decision maker would receive one lottery ticket for each point he or she would gain in the decision game. In this condition, we assumed that punitive sentiment would be a relevant motive, unlike fear and greed. In the other's decision is consequential to both self and other 
condition, participants were told that they would receive one lottery ticket for each point gained in the decision game, and that the decision maker would receive one lottery ticket for each point gained in the decision game. In this condition, we assumed that fear, greed, and punitive sentiment would all be relevant motives.

Dependent measures. The measures for accurate information and for inaccurate information were the same as in Experiment 1. Honesty ("I tried to be honest"), fear ("I tried to avoid being exploited"), greed ("I intended to enhance my own outcome"), and punitive sentiment ("I wanted to teach the other a lesson") were assessed on five-point scales ( 1 = "not at all" to 5 = "very much"). Participants then answered manipulation checks (see Results section), and were paid and debriefed.

Results

Treatment of the data and manipulation checks. Nine participants who incorrectly answered one or both manipulation checks about the allocation of lottery tickets were excluded from the sample. All analyses are based on the remaining 68 participants. As intended, participants rated the other as competitive. Ratings were above the scale mean (3.0), $t(67)=15.66, p<.001$, and were not influenced by condition, $F(2,65)<1$.

Descriptive statistics. Table 4 shows that the desire to be honest was positively correlated with giving accurate information, and negatively with giving inaccurate information. Fear was positively correlated with giving inaccurate information and negatively correlated with giving accurate information. Greed was negatively correlated with giving accurate information, and positively with giving inaccurate information. Punitive sentiment had a significant negative correlation with giving accurate information, and a positive but not significant correlation with giving inaccurate information. Finally, fear and greed were not correlated, but fear and punitive sentiment were moderately correlated.

Motives for lying and deception. To examine whether our experimental manipulations 
influenced fear, greed, and punitive sentiment, we conducted three separate analyses of variance with condition as independent variable and motive as dependent variable. The effect of condition on fear was in the expected direction, $F(2,65)=3.06, p<.085$. In both conditions in which other's decision was consequential for one's own outcomes, that means, in the consequential only to self condition and in the consequential to self and other condition, participants indicated that fear was a motive $(M=3.81, S D=1.13$; and $M=3.84$, $S D=1.17$, respectively), as they answered above the scale mean $(t(25)=3.64, p<.001$, and $t(18)=3.15, p<.01$, respectively). In the condition in which other's decision was not consequential to the own outcome, participants indicated less fear $(M=3.17, S D=1.50)$ than in the other two conditions, $t(66)=2.00, p<.05$.

There was a significant effect of condition on greed, $F(2,65)=14.44, p<.001$. When other's decision was consequential only to own outcomes $(M=4.46, S D=0.81)$, or to both own and other's outcomes $(M=4.47, S D=0.96)$, participants reported high levels of greed, which did not differ according to Duncan test $(\mathrm{p}<.05)$. When other's decision was inconsequential for one's own outcomes, however, greed was lower $(M=2.96, S D=1.93)$ and differed significantly from the other conditions.

There was no main effect of condition on punitive sentiment, $F(2,65)<1$, ns (overall $M=2.81, S D=1.38)$. Together, these results support the conclusion that our experimental manipulations influenced fear and greed. The manipulations did not influence punitive sentiment. We return to this in the discussion section.

Provision of accurate and inaccurate information. The amount of accurate and inaccurate information was analyzed in a 3 (condition) x 2 (information: accurate vs. inaccurate) ANOVA with the last factor as a within-participant variable. A main effect of information, $F(1,65)=67.93, p<.001$, indicated that participants gave more inaccurate $(M=4.10, S D=1.98)$ than accurate information $(M=1.07, S D=1.54)$. This makes sense 
because in all conditions the other was competitive, and the means are indeed similar to those in the competitive-other condition of Experiment 1.

Results further revealed a significant interaction of information with condition, $F(2,65)=4.99, p<.01$. Table 5 shows that participants gave more accurate information and less inaccurate information when other's decision was inconsequential rather than consequential to the participant's outcomes. Further, participants provided less accurate and more inaccurate information when other's decision was consequential to both the participant's and the decision maker's outcomes than when other's decision was consequential only to the participant's outcomes. This is consistent with the idea that fear and greed motivate the provision of accurate and inaccurate information.

Tests for mediation. Experimental manipulations influenced fear (marginally significant) and greed, as well as the provision of accurate and inaccurate information. Fear and greed were also correlated with the provision of accurate and inaccurate information. This means that fear and greed qualify as a potential mediator between experimental manipulations and the provision of accurate and inaccurate information. However, mediation also requires that the effect of the manipulations on the provision of accurate and inaccurate information is reduced when the mediator is taken into account, and that the reduction in regression weight from simple to multiple regression is significant (Kenny, Kashy, \& Bolger, 1998).

To verify whether the additional requirements hold up for fear, and greed, we performed per motive two regression analyses (one with accurate information, and one with inaccurate information as dependent variable) with experimental condition as the independent variable. A regression analysis with the provision of accurate information as dependent variable, experimental manipulations as independent variable, and fear as mediator revealed that the originally significant effect of experimental manipulations $(\beta=-.35, t=-3.06, p<$ $.003)$ dropped slightly $(\beta=-.29, t=-2.58, p<.012)$. The predicted reduction in regression 
weight from simple to multiple regression was marginally significant, $Z=1.69, p<.10$. A regression analysis with the provision of inaccurate information as dependent variable, experimental manipulations as independent variable, and fear as mediator revealed that the originally significant effect of experimental manipulations $(\beta=.33, t=2.83, p<.006)$ remained almost unaffected $(\beta=.31, t=2.57, p<.013)$. Indeed, the reduction in regression weight from simple to multiple regression was not significant, $Z<1$. Thus, there is some evidence that fear partially mediates the effect of experimental manipulations on the provision of accurate information, but not the provision of inaccurate information.

A regression analysis with the provision of accurate information as dependent variable, experimental manipulations as independent variable, and greed as mediator revealed that the originally significant effect of experimental manipulations $(\beta=-.35, t=-3.06, p<$ .003 ) dropped substantially $(\beta=-.17, t=-1.35, \mathrm{~ns}$.). The reduction in regression weight from simple to multiple regression was significant, $Z=-2.55, p<.05$. A regression analysis with the provision of inaccurate information as dependent variable, experimental manipulations as independent variable, and greed as mediator revealed that the originally significant effect of experimental manipulations $(\beta=.33, t=-2.83, p<.006)$ dropped substantially $(\beta=.15, t=-$ $1.18, \mathrm{~ns}$.$) . The reduction in regression weight from simple to multiple regression was$ significant, $Z=2.27, p<.05$. These results show that greed mediates between experimental manipulations and the provision of both accurate and inaccurate information.

Direction of deceit. The information provided in each of the six cells was submitted to a 3 (condition) x 2 (issue: A vs. B) x 3 (level: x vs. y vs. z) ANOVA, with the last two variables as within-participant factors. Question marks were regarded as missing data, which led to the exclusion of 14 participants. Results revealed a main effect of level, $F(2,40)=$ $10.71, p<.001$, showing that participants pretended that to them level $\mathrm{x}$ was most valuable 
$(M=5.35, S D=5.35)$, that level y was intermediate $(M=1.28, S D=3.54)$, and that level $\mathrm{z}$ was the least valuable $(M=-1.85, S D=5.93)$. There was no significant interaction with condition $(F(4,82)=1.36, \mathrm{~ns})$.

We also examined whether the number of participants suggesting they would get negative outcomes when the other gets zero differed as a function of experimental condition. For issue $\mathrm{A}$ and issue $\mathrm{B}$, condition had no effects, both $\chi^{2}(2, N=68)<1.37, p \mathrm{~s}>.50$. However, consistent with the competitive other condition of Experiment 1, 24 out of 68 participants (35\%), and 25 out of 68 participants (37\%) suggested they received negative outcomes in cell zA and zB, respectively. We then examined the number of participants suggesting their outcomes exceeded those of the other (cells $\mathrm{xA}$ and $\mathrm{xB}$ of the payoff matrices shown in Table 1). Again, for issue A and issue $\mathrm{B}$, condition had no effects, both $\chi^{2}(2, N=$ $68)<4.40, p s>.12$. Consistent with the competitive other condition of Experiment 1, however, 27 out of 68 participants (40\%), and 40 out of 68 participants (59\%) suggested their outcomes exceeded those of their counterpart in cell xA and xB, respectively. These results support Hypothesis 2 that with a competitive other people tend to misrepresent outcomes so that it appears as if they receive negative outcomes when the other gets zero, and that their outcomes exceed others' outcomes when these are positive.

\section{Discussion and Introduction to Experiment 3}

Experiment 2 showed that giving accurate information is partially motivated by fear of being exploited, and by greed. Giving inaccurate information is motivated by greed only. Punitive sentiment, while negatively correlated with giving accurate information, did not mediate effects of experimental conditions.

Measurement issues may account for the weak results regarding punitive sentiment. Indeed, single-item measures were used and although meaningful correlations among these measures, and with giving accurate and inaccurate information were found, it cannot be 
excluded that some measures were not very good. Alternatively, it may be that punitive sentiment is a motive that exists in some people more than in others, and is unlikely to be triggered temporarily by experimental manipulations like the ones we used in Experiment 2. In fact, it can be argued that selfish individuals who are solely concerned with their own outcomes tolerate others who are selfish more than pro-social individuals who are concerned with fairness and collective welfare.

Individuals with a selfish orientation tend towards non-cooperative behavior, whereas those with a pro-social orientation tend to trust others and approach them in an open-minded and cooperative way (Pruitt \& Kimmel, 1977; Van Lange, 1999). When, however, the other is competitive, pro-social individuals "over-assimilate" and respond even more competitively than selfish individuals (e.g., Kelley \& Stahelski, 1970; Van Lange, 1992). Over-assimilation may be grounded in punitive sentiment and the moralistic desire the "teach the other a lesson," or in the belief that being overly competitive persuades the other to change his or her behavior towards a more cooperative course (Price et al., 2002).

In Experiment 2 punitive sentiment was negatively correlated with the provision of accurate information, and we reviewed arguments and evidence that pro-social individuals may be guided by punitive sentiment more than individuals with a selfish orientation. Parallel to the over-assimilation effect observed in social dilemmas, it then follows that pro-social, as compared to selfish individuals, will be more accurate towards a cooperative other, and more inaccurate towards a competitive other (Hypothesis 3). Initial evidence for this hypothesis comes from a negotiation study by O'Connor and Carnevale (1997) who found more lying and deception when both members of a dyad had a pro-social (i.e., maximize joint outcomes) rather than selfish goal (maximize personal outcomes). However, because dyad members in this study received the same goal instructions, their findings may reflect (1) a main effect of other's cooperative or competitive goals (our Hypothesis 1); (2) a main effect of the 
participant's pro-social versus selfish orientation (O’Connor \& Carnevale's hypothesis); or (3) an interaction between the participant's value orientation and other's cooperative versus competitive goal (our Hypothesis 3).

\section{Method}

Participants and design. One hundred and fifty students (58 male and 92 female) at the University of Amsterdam participated in the experiment and received 20 Dutch guilders (approx. US\$ 8). All participants were placed in the zero-sum task condition of Experiment 1. The design was a 2 (social value orientation: pro-social vs. selfish) x 3 (other's motivation: cooperative, competitive, unknown) between-participants factorial, with as main dependent variables the information provided and self-reported strategies.

Procedure and measurement of social value orientation. The procedure was the same as in Experiment 1, except that prior to the experiment we measured social value orientation using the decomposed game method developed by Kuhlman and Marshello (1975). This method has good construct validity (Van Lange, 1999), internal consistency (e.g., Liebrand \& Van Run, 1985) and test-retest reliability (Kuhlman, Camac, \& Cunha, 1986). Participants were presented with nine triple-dominance games. In each game, participants choose between option A, B, and C. In one of these games, for example, option A pays 550 points to oneself and 500 points to an unknown other, option B pays 500 points for oneself and 100 points for the other, and option C pays 500 points for both oneself and the unknown other. Option A represents the individualistic choice because one's own outcomes are larger (550) than are those in option B or C (both 500 points). Option B represents the competitive choice because it provides a greater advantage over the other's outcomes $(500-100=400)$ than either option A $(550-300=250)$ or option C $(500-500=0)$. Finally, option C corresponds to a pro-social choice because it provides equality and a larger joint outcome $(500+500=1000)$ than either option A $(550+300=850)$ or option B $(500+100=600)$. 
To be classified in one of the three social value orientations, participants had to choose consistently on at least six of the nine trials. In the current study, 39\% ( $n=59)$ could be classified as pro-social, $44 \%(n=66)$ could be classified as individualistic, and 5\% $(n=8)$ could be classified as competitive. This distribution is consistent with earlier research (e.g., De Dreu \& Van Lange, 1995; Liebrand \& Van Run, 1985). Like earlier research (e.g., De Dreu \& Van Lange, 1995; Liebrand \& Van Run, 1985; Van Lange \& Kuhlman, 1994), we combined competitive and individualistic participants into a broader category labeled "selfish." We excluded 17 participants (11\%), because they were unclassifiable.

After the decomposed game measure, participants were given a 10-minute filler task, and then went on with the same procedure as in Experiment 1.

Dependent measures. These were the same as in Experiment 1.

Results

Manipulation check. A 3 (other's motivation: cooperative, competitive, unknown) x 2 (own social value orientation: pro-social vs. selfish) ANOVA of the ratings of other's competitiveness only showed a significant main effect of other's motivation, $F(2,127)=$ $16.83, p<.001$. Duncan test $(\mathrm{p}<.05)$ revealed that a competitive other rated as significantly more competitive $(M=4.00, S D=1.11)$ than both a cooperative other $(M=2.63, S D=1.23)$ and an unknown other $(M=3.00, S D=0.96)$, which did not differ significantly.

Provision of accurate and inaccurate information. The amount of accurate and inaccurate information was analyzed in a 3 (other's motivation: cooperative, competitive, unknown) x 2 (own social value orientation: pro-social vs. selfish) x 2 (information: accurate vs. inaccurate) ANOVA, with the last factor within participants. A within-participant main effect for information showed that participants gave more inaccurate information $(M=3.32$, $S D=2.19)$ than accurate information $(M=1.99, S D=2.07), F(1,127)=18.07, p<.001$. This effect was qualified by a significant interaction between information and other's motivation, 
$F(2,127)=16.63, p<.001$. As predicted in Hypothesis 1, participants gave least accurate and most inaccurate information in the competitive other condition, more accurate information in the unknown other condition, and most accurate and least inaccurate information in the cooperative other condition (see Table 6).

The predicted three-way interaction among information, other's motivation, and social value orientation, was significant, $F(2,127)=3.46, p<.05$. Compared to selfish participants, pro-social individuals gave more accurate information when the other was cooperative, and less accurate information when the other was competitive (see Table 6). Furthermore, compared to selfish participants, pro-social individuals gave less inaccurate information when the other was cooperative. And although not significant, pro-social individuals gave, relative to selfish individuals, more inaccurate information when the other was competitive (see Table 6). All in all, these results support Hypothesis 3.

Direction of deceit. As in Experiment 1, we analyzed the information participants gave in the six cells in a 3 (other's motivation) x 2 (social value orientation) x 2 (issue A vs. issue B) x 3 (level x vs. y vs. z) ANOVA with the last two factors within participants.

Question marks were treated as missing values, which led to the exclusion of 40 participants.

Results revealed, first of all, a within-participants main effect of issue, $F(1,87)=$ $49.24, p<.001$, showing that participants correctly stated that they got more points on issue A $(M=1.87)$ than on issue B $(M=0.68)$. As in Experiment 1 , an interaction between issue and level, $F(2,174)=3.75, p<.005$, showed that participants accurately stated that yA $\left(M_{y A}\right.$ $=1.89)$ provided more value $\mathrm{yB}\left(M_{y B}=0.78, t(92)=5.67, p<.001\right)$ and that cell $\mathrm{zA}\left(M_{z A}=\right.$ 2.42) provided more value than cell $\mathrm{zB}\left(M_{z B}=0.31, t(92)=5.45, p<.001\right)$, but that cell $\mathrm{xA}$ $\left(M_{x A}=1.31\right)$ gave as little value as cell xB $\left(M_{x B}=0.95, t(92)=0.85, n s\right)$.

There was a significant interaction between level and other's motivation, $F(6,174)=$ $17.59, p<.001$, indicating that the information given to cooperative others increased from $M$ 
$=-2.01$ at level $\mathrm{x}$ to $M=1.20$ at level $\mathrm{y}$ to $M=2.87$ at level $\mathrm{z}$. The information given to competitive others, however, decreased from $M_{\mathrm{x}}=5.70$ points to $M_{\mathrm{y}}=1.32$ to $M_{\mathrm{z}}=-2.14$. This pattern is similar to the one found in Experiment 1 and provides new support for Hypothesis 2.

A significant interaction among issue, level, and other's motivation further qualified this finding, $F(4,174)=9.82, p<.001$, and showed that, dependent on the other's motivational goal, issue mattered on different levels. In the competitive-other condition, participants pretended to get more points in cell $\mathrm{xA}(M=7.04, S D=4.58)$ than in cell $\mathrm{xB}(M$ $=4.36, S D=4.52 ; t(27)=5.49, p<.001)$, while issue did not matter on level y $\left(M_{A}=1.57\right.$, $S D=4.61$, vs. $M_{B}=1.07, S D=3.91 ; t(27)=1.17$, ns $)$ and level z $\left(M_{A}=-2.04, S D=6.04\right.$, vs. $\left.M_{B}=-2.25, S D=4.53 ; t(27)<1, \mathrm{~ns}\right)$. In the cooperative-other and the unknown-other condition, however, issue did not matter on level $\mathrm{x}$, but it did matter on level y and level $\mathrm{z}$. Towards a cooperative other, participants told that they would get $M_{A}=-2.68(S D=5.69)$ points in cell xA and $M_{B}=-1.34(S D=4.69)$ in cell $\mathrm{xB}$, which did not differ significantly, $t(37)=-1.66$, ns. On level $\mathrm{y}$, they pretended to get more points in cell yA $(M=1.97, S D=$ $2.38)$ than in cell $\mathrm{yB}(M=0.42, S D=1.65 ; t(37)=8.28, p<.001)$, and on level $\mathrm{z}$, they pretended to get more points in cell zA $(M=4.39, S D=3.05)$ than in cell $\mathrm{zB}(M=1.18, S D=$ $1.98 ; t(37)=9.28, p<.001)$. Similarly, participants told an unknown other that they would get $M_{A}=1.00(S D=6.78)$ points in cell xA and $M_{B}=0.63(S D=6.48)$ in cell xB, which did not differ significantly, $t(26)<1$, ns. On level y, they pretended to get more points $(M=2.11$, $S D=1.55)$ in cell yA than in cell yB $(M=1.00, S D=1.82 ; t(26)=2.68, p<.02)$, and on level z, they pretended to get more points $(M=4.26, S D=5.32)$ in cell zA than in cell zB $(M$ $=1.74, S D=4.78 ; t(26)=2.68, p<.02)$.

We also examined the number of participants suggesting they would get negative outcomes when the other gets zero as a function of other's motivation and social value 
orientation. For issue A, a logistic regression with other's motivation, social value orientation, and their interaction as independent variables showed a significant effect involving other's motivation, $B=3.21, p<.01$. Fewer people in the cooperative other condition ( 1 out of 48 , $2 \%$ ) and the other-unknown condition ( 3 out $42,7 \%$ ) suggested they received negative outcomes than in the competitive other condition ( 15 out of $43,35 \%)$. A similar pattern was found for issue $\mathrm{B}, B=2.28, p<.01$ : Fewer people in the cooperative other condition ( 3 out of $48,6 \%$ ) and the other-unknown condition ( 3 out of $42,7 \%$ ) suggested they received negative outcomes than in the competitive other condition (17 out of $43,40 \%)$. We then examined the number of participants suggesting their outcomes exceeded those of the other (cells xA and $\mathrm{xB}$ of the payoff matrices shown in Table 1) as a function of other's motivation and social value orientation. For issue A, logistic regression showed a significant effect, $B=3.94, p<$ .02. Fewer people in the cooperative other condition (1 out of $48,2 \%)$ and the other-unknown condition (9 out of 42,21\%) suggested their outcomes exceeded those of their counterpart than in the competitive other condition (21 out of 43,49\%). A similar pattern was found for issue $\mathrm{B}, B=3.27, p<.001$ : Fewer people in the cooperative other condition ( 2 out of $48,4 \%$ ) and the other-unknown condition (11 out of 42, 26\%) suggested their outcomes exceeded those of their counterpart than in the competitive other condition ( 23 out of $43,54 \%$ ). In all four logistic regression analyses, own social value orientation and the interaction of own social value orientation and other's motivation had no significant influence, all $p \mathrm{~s}>.50$

All in all, these results provide new support for Hypothesis 2: People with a competitive counterpart are more likely to misrepresent their outcomes as negative when the other gets zero, and as exceeding other's positive outcomes. Social value orientation did not qualify this general pattern.

Self-reported strategies. Consistent with the above results, $61 \%$ of the participants with a competitive other stated that they entered a high number to deter the other from 
choosing that cell. This percentage was much lower in the case of a cooperative other $(17 \%)$ or in the case of an unknown other $(20 \%), \chi^{2}(2, N=133)=18.64, p<.001$. Likewise, $84 \%$ of the participants with a competitive other reported having entered a low number to make the other choose that cell, while only $29 \%$ of participants with a cooperative other indicated to have applied that strategy. Participants with an unknown other $(43 \%)$ were in between, $\chi^{2}(2$, $N=133)=28.70, p<.001$. Finally, almost all participants with a competitive other $(98 \%)$, but only $58 \%$ of those with a cooperative other stated that they had tried to mislead the other. Participants with an unknown other $(83 \%)$ were in between, $\chi^{2}(2, N=133)=21.83, p<.001$.

\section{Discussion and Introduction of Experiment 4}

Experiment 3 replicates and extends Experiment 1 and 2. As predicted in Hypothesis 1, we found that individuals with a cooperative other were most likely to give accurate information and least likely to give inaccurate information, while the reverse holds for individuals with a competitive other. As predicted in Hypothesis 3, this general pattern was stronger for pro-social individuals than for selfish individuals, which is indicative of an overassimilation effect. Results for the direction of deceit were also consistent with those obtained in Experiment 1, and once again supported Hypothesis 2. Individuals with a cooperative other truthfully present the situation as involving opposing interests, whereas individuals with a competitive other misrepresent their outcomes as negative when other's outcome is zero, and as exceeding other's outcomes when these are positive. Social value orientation did not influence this pattern, suggesting that pro-social and selfish individuals do not differ in their strategic misrepresentation.

Some limitations are noteworthy. First, the Information Provision Game is abstract and context-free. The reader may wonder whether behavior in this game informs us about strategic misrepresentation in daily settings. The first goal of Experiment 4 was to replicate 
the design of Experiment 3 in a different setting with a different scenario (i.e., the sale of one's used car) and to submit Hypothesis 1 and 3 to a new test. Second, the use of psychology undergraduates in the first three experiments could be seen as a limitation. Because replicating results with a random sample drawn from the general population would further increase confidence in the generality of the findings, in Experiment 4 we sampled participants from the general population.

\section{Method}

Experimenters, participants and design. Five M.A. students at the University of Amsterdam (3 female and 2 male) addressed a random sample of people on a busy market place in Amsterdam, and in a commuter train connecting the inner city of Amsterdam with a suburban office and middleclass housing area. Individuals were asked to fill out a brief questionnaire, in return for a chance of winning $€ 20$ in a lottery (approx. US\$20). About $40 \%$ of the people approached agreed to participate $(N=179)$. The most frequently mentioned reasons not to participate were not being able to read and write Dutch, or having no time. Fifty-seven percent $(n=101)$ of the participants were male, and the mean age was 25 (range between 19 and 59 years). Although 18\% $(n=33)$ did not have the Dutch nationality, all participants were fluent in Dutch. Participants were assigned at random to one of three conditions (other's motivation: competitive, cooperative, or unknown). Social value orientation was included in the design as a post-hoc blocking factor. Main dependent variables were perception of other's personality, and the likelihood of presenting accurate and inaccurate information.

Procedure and materials. When an individual agreed to participate, he or she received the questionnaire and was given about 10 minutes to read the materials and answer the questions. To provide the participants with some privacy and still be able to assist should something be unclear, the experimenters left them alone for a while but remained nearby. 
After about 10 minutes the experimenter collected the materials, briefly explained the purpose of the study, and wrote down the name and address of the participant if he or she wanted to participate in the lottery.

The questionnaire was introduced as a study about how people make decisions involving the purchase of goods and services. Immediately thereafter, we assessed the participant's social value orientation using a paper-and-pencil version of the decomposed game method employed in Experiment 3. Twenty-eight per cent of the participants $(n=51)$ were pro-socially motivated, $17 \%(n=30)$ were competitively motivated, $42 \%(n=75)$ were individualistically motivated, and $13 \%(n=23)$ could not be classified. The relatively low percentage of pro-socials (28\%) is not inconsistent with previous research (e.g., De Dreu \& McCusker, 1997; Dehue, McClintock, \& Liebrand, 1993), and suggests no preponderance of helpful people with a pro-social orientation. As in Experiment 3, competitively and individualistically motivated individuals were combined into the overarching category "selfish."

Once participants had completed the value orientation measure, they were asked to imagine selling their car. They read an advertisement they had, presumably, placed in a local newspaper (i.e., information available to the potential buyer as well). They were also given some background information about the car that was not mentioned in the advertisement (i.e., not available to the potential seller), which created opportunity for deception and misrepresentation. Specifically, it was explained that the odometer had been replaced, so that the actual mileage of the car was higher than displayed on the odometer, that the gearshift worked properly, but would need to be replaced in the nearby future, that they did not care for the radio and intended to leave it in the car, and that they wanted to keep the car for a few more weeks before actually selling it.

Manipulation of other's motivation. Participants were then told to imagine meeting a 
prospective buyer (all scenarios involved a male potential buyer) they recalled from a party some time ago, who himself, however, did not recognize them. In the cooperative-other condition, they read that they remembered the prospective buyer as a pleasant and warm person who was interested in other people and seemed to care for other people's well being. In the competitive-other condition, participants read that they remembered him as an unpleasant and cold person who was interested in himself only and did not appear to consider other people's well being. In the unknown-other condition, participants read that while they remembered having met the person before, they could not remember any details about him.

Dependent variables. Participants were presented with four brief scenarios. In each scenario, the buyer mentions one of the features of the car he was unaware of. The participant was then asked to rate the likelihood of responding by providing accurate information and of reacting with an active lie (on scales from $1=$ very unlikely, to $5=$ very likely).

In the first scenario, the buyer mentions the low mileage. Participants were asked to indicate whether they would inform the buyer about the replacement of the odometer and provide accurate information about the actual mileage (first accurate information), and whether they would confirm the buyer's observation and stress the low mileage (first active lying). In the second scenario, the buyer inquires about the condition of the gearshift. Participants were asked whether they would tell the buyer that it needs to be fixed soon (second accurate information), and whether they would tell the buyer that the gearshift was fine (second active lying). In the third scenario, the buyer asks if he could buy the radio. Participants were asked to indicate whether they would tell the buyer that they wanted to leave it in the car anyway (third accurate information), and whether they would say that they wanted to keep the radio, but would sell it for a higher price than what the buyer offered (third active lying). Finally, in the fourth scenario, the buyer asked if he could buy the car, but take it over one month later. Participants were asked to indicate whether they would mention 
that they also favored to keep the car another month (fourth accurate information), and whether they would state that keeping the car causes difficulties and that this would only be possible when the buyer pays a higher price in return (fourth active lying).

After the respondents had indicated their responses to the four scenarios, they were asked how they perceived the prospective buyer. As in the first three experiments, participants rated the other party's competitiveness. Because participants filled out the questionnaire in noisy environments, we included several instruction checks in which crucial aspects of the scenarios were repeated and participants were asked to indicate, without looking back, whether the statement was true or false. Finally, age, gender, and nationality was assessed, and, to control for negotiation experience, participants were asked how often they negotiate at work $(1=$ hardly ever, to $5=$ very often $)$, and how often they had sold a car in the past 10 years.

Results

Treatment of the data and manipulation checks. Eight respondents had to be removed from the sample due to missing values, another fourteen were removed because they answered one or more instruction checks incorrectly, and twenty-three respondents were removed because they could not be classified as pro-social or selfish. All analyses were based on the data of 136 participants. Demographic variables were neither associated with the provision of accurate or inaccurate information, nor did they interact with other's motivation or social value orientation.

A 3 (other's motivation) x 2 (social value orientation) ANOVA on the ratings of other's competitiveness revealed a main effect of other's motivation, $F(2,127)=4.15, p<$ .02 , showing that the buyer was seen as more cooperative in the cooperative-other condition $(M=1.98, S D=0.96)$ than in the competitive-other condition $(M=2.51, S D=1.30)$. In the unknown-other condition, ratings were intermediate $(M=2.12, S D=0.88)$ and did not differ 
from the other two according to a Duncan test $(p<.05)$. A main effect of own social value orientation, $F(1,127)=13.22, p<.001$, revealed that pro-social participants rated their buyer as more cooperative $(M=2.67, S D=1.20)$ than did selfish participants $(M=2.00, S D=$ $0.96)$.

Provision of accurate and inaccurate information. Scores of accurate information and of active lying were entered as dependent variables into a 3 x 2 x 4 x 2 ANOVA with other's motivation (cooperative vs. competitive vs. unknown) and own social value orientation (prosocial vs. selfish) as between-participants factors and scenario (1 vs. 2 vs. 3. vs. 4) and information (accurate information vs. active lying) as within-participants factor. A main effect of information revealed that, overall, participants considered it more likely to provide accurate information than to engage in active lying $(M=3.16, S D=1.02$; vs. $M=2.37, S D=$ $0.87 ; F(1,130)=27.40, p<.001)$. A significant main effect of scenario, $F(3,128)=26.51$, and an interaction of scenario with information, $F(3,128)=9.22$ (both $p \mathrm{~s}<.001$ ), indicated in the third scenario (selling the radio instead of giving it the seller for free), both active lying and provision of accurate information was rated as more likely than in the other scenarios, and that in the fourth scenario (asking money for handing over the car some weeks later, despite the fact that this was profitable for the seller as well) lying was rated more likely than in the other three scenarios.

Of greater theoretical importance is the significant interaction of information with other's motivation, $F(2,130)=18.89, p<.001$, indicating that participants rated it more likely to give accurate information to a cooperative $(M=3.59, S D=0.97)$ rather than competitive other $(M=2.58, S D=0.81)$, with an unknown other in between $(M=3.24$, $S D=0.98)$. Participants also rated it more likely to actively deceive a competitive $(M=2.79$, $S D=0.95)$ rather than cooperative buyer $(M=2.02, S D=0.59)$, with an unknown buyer falling in between $(M=2.36, S D=0.87)$. This pattern of results supports Hypothesis 1 and 
validates the results of Experiments 1 to 3.

ANOVA also revealed an interaction among information, own social value orientation, and other's motivation, $F(2,130)=5.90, p<.01$. As predicted in Hypothesis 3 , the effect of other's motivation was stronger for pro-social participants than for selfish ones. Table 7 shows the means for providing accurate information and for active lying (collapsed over scenario). In the cooperative-other condition, pro-social individuals were more willing to give accurate information than did selfish individuals. In the competitive-other condition, however, pro-social individuals were less willing to give accurate information than did selfish participants. This effect reflects the over-assimilation phenomenon predicted in Hypothesis 3, and validates the findings of Experiment 3. In the unknown-other condition, pro-socials tended to rate being accurate as more likely than selfish individuals, but this difference was not significant.

\section{General Discussion}

Lying and deception have been studied in a variety of disciplines, from a variety of perspectives. In social psychology, the bulk of the research effort has been focused on discovering whether and how people's emotional display and nonverbal expressions change when telling lies in contrast to telling the truth (e.g., DePaulo, 1992; Ekman et al., 1988), and vice versa, whether and to what extent people are able to distinguish liars from truth-tellers (e.g., Vrij, 2001). In the current study, we approached the issue from a different angle and examined when, how, and why people in social decision-making engage in lying and deception. Based on interdependence theory (Kelley \& Thibaut, 1978; Rusbult \& Van Lange, 1996, 2003) and related research conducted in the behavioral decision tradition (e.g., Boles et al., 2000; Schweitzer \& Croson, 1999; Murnighan et al., 1999), several hypotheses were developed and tested by means of a newly developed Information Provision Game. In a nutshell, results showed that (1) individuals engage in more lying and deception when their 
counterpart is competitive rather than cooperative; (2) the provision of accurate and inaccurate information is correlated with fear of being exploited, with greed, and with punitive sentiment; (3) individuals deceive a competitive other because of greed, fear of exploitation, and perhaps also because of the activation of punitive sentiments; (4) compared to individuals with a selfish orientation, those with a pro-social orientation are more honest towards a cooperative other and more deceitful towards a competitive other; and (5) regardless of their social value orientation, individuals deceive a competitive other in such a way that their outcomes appear negative when the other gets zero, and as exceeding other's outcomes when the other gets positive outcomes.

Theoretical Implications

Our work built upon two related theoretical accounts--interdependence theory (Kelley \& Thibaut, 1978; Rusbult \& Van Lange, 1996, 2003), and goal expectation theory (Pruitt \& Kimmel, 1977). We further used insights from research in a behavioral decision tradition (Boles et al., 2000; Schweitzer \& Croson, 1999; Kagel \& Roth, 1995; Murnighan et al., 1999). Our study contributes to each of these lines of inquiry and we will discuss them consecutively.

Goal expectation theory derives from, and largely focuses on, cooperative and competitive choice behavior in the context of classic experimental games like the Prisoner's Dilemma Game. It predicts that individuals become cooperative only when they (a) have cooperative goals, and (b) expect their counterpart to have cooperative goals too (Pruitt \& Kimmel, 1977). Our results are highly consistent with this general prediction, and extend goal expectation theory to the domain of lying and deception. That is, from our experiments we can conclude that individuals provide truthful information only when (a) their counterpart is believed to be cooperative, and (b) they themselves have a pro-social value orientation.

Goal expectation theory is related to interdependence theory, developed by Kelley and 
Thibaut (1978; Rusbult \& Van Lange, 1996). Like goal expectation theory, interdependence theory is primarily concerned with cooperative and non-cooperative behavior in Prisoner's Dilemma type of situations (for recent extensions towards other interdependent situations such as negotiation, and close relationships, see e.g., De Dreu \& Van Lange, 1995; Van Lange, Agnew, Harinck, \& Steemers, 1997). Within interdependence theory, social value orientations and expectations about other's goals and intentions play a key role. As far as we know, however, no past research explicitly considered lying and deception as a function of social value orientation, or expectations about other's goals. The fact that our results were highly consistent with findings obtained in more traditional research focusing on cooperative and non-cooperative choice behavior indicates that key features of interdependence theory also apply to other types of behavior than cooperative and non-cooperative choices.

Consistent with both goal expectation theory and interdependence theory, we obtained strong evidence that lying and deception vis-à-vis a competitive other is motivated by a desire to do well oneself (greed), and some evidence that it is motivated by fear of being exploited. It is interesting to note that greed appeared to motivate withholding accurate information as well as giving inaccurate information. Fear, in contrast, appeared to motivate only withholding accurate information, and was not related to giving inaccurate information. In other words, our results suggest that greed motivates a reduction in cooperative behavior, as well as an increase in competitive behavior, while fear only motivates a reduction in cooperative behavior. This may indicate that fear of being exploited activates avoidance tendencies and a desire to escape the situation, whereas greed activates an approach tendency. Intuitively this seems appealing, but research is needed to examine this issue. Also, this result suggests that being honest and being deceptive are not the end points of one and the same continuum. Rather, they appear to be different types of behavior that can be motivated by the same, or by different goals. 
Taking account of recent theory and research, we proposed a third possible motive underlying lying and deception, namely punitive sentiments (Price et al., 2002; see also Folger \& Skarlicki, 2001). In Experiment 2, we found that lying and deception were positively correlated with punitive sentiment, but we were unsuccessful in manipulating various levels of punitive sentiment. Drawing on social dilemma research, we argued that punitive sentiment may be stronger for some individuals than for others. Consistent with this, Experiment 3 and 4 revealed the so-called over-assimilation effect--the tendency for prosocial individuals to be even more competitive (i.e., deceptive) towards competitive others than selfish individuals are (Kelley \& Stahelski, 1970; Van Lange, 1992). The overassimilation effect is usually explained by arguing that pro-social individuals try to "teach the competitive other a lesson," an explanation strongly compatible with the punitive sentiment motive studied in Experiment 2. Results could have been stronger, because the test for mediation in Experiment 2 failed, and no measures of punitive sentiment were included in Experiment 3 and 4. Nevertheless, results suggest that lying and deception can be motivated by punitive sentiments--the desire to punish the other for observed or expected wrongdoing. Future research could examine this issue in more detail.

Our experimental game, and some of our predictions, were inspired by research conducted in a behavioral decision approach to mixed-motive interdependence. Within this approach, decision makers are assumed to be bounded in their rationality but otherwise motivated to maximize own profit as much as possible (e.g., Boles et al., 2000; Kagel \& Roth, 1995). Current findings contradict this assumption at least to some extent, in that they show that lying and deception were influenced by the participant's social value orientation as well as by the participant's beliefs about the other's cooperative or competitive motivation. The influence of social value orientations indicates that individuals are motivated by other considerations than their immediate self-interest (for a discussion, see Rusbult \& Van Lange, 
1996). The influence of beliefs about other's cooperative or competitive motivation is particularly troublesome for the behavioral decision approach, because self-interest dictates as much misrepresentation when the other is cooperative, as when the other is competitive. It cannot be understood in terms of immediate self-interest that individuals in a one-shot mixedmotive situation are open and honest when they believe their counterpart is cooperative (see also Paese \& Gilin, 2000).

In contrast to previous research on lying and deception in social decision making, the current study allowed us not only to examine the extent to which individuals misrepresent their preferences and priorities, but also the direction in which they try to mislead their counterpart. Participants knew the situation was one in which own and other's interests were opposed--the more the decision maker would get the less they themselves would obtain, and vice versa. As decision makers were only informed about their outcomes, and not about those of the participant, they were ignorant about the exact structure of the situation. Participants could accurately or inaccurately describe the situation to the decision maker by providing accurate or inaccurate information about their own prospective outcomes, and thus influence the alleged consequences of the counterpart's decision making for both the other's and their own outcomes. Experiment 1 and 3, moreover, showed that when facing a cooperative other, participants provided information that would (accurately) indicate they and their counterpart were in an opposed-interest situation. When facing a competitive other, participants gave information that would (inaccurately) indicate they and their counterpart were in a situation in own outcomes were negative when the other gets zero, and exceeding other's outcomes when these are positive (see also Figure 2).

Why would one accurately describe a situation as involving opposed interests when the other is believed to be cooperative, and inaccurately describe the situation as involving compatible interests when the other is believed to be competitive? The answer to this 
question may be that facing a cooperative other triggers a cooperative mind-set that directs the participant towards honesty and cooperative behavior. This results in the provision of accurate information and, by default, a description of the situation as involving opposed interests. Given the other pursues a cooperative goal and seeks a fair distribution, this pattern of honest and accurate behavior may result in the other favors the mid-point of the scale in the decision game (i.e., level y), thus providing both him- or herself and the participant with equally distributed outcomes that are neither great nor bad from a personal perspective. Facing a competitive other, in contrast, triggers a competitive mind-set that directs the participant towards dishonesty and competitive behavior. Greed, and to some extent fear, leads one to misrepresent one's preferences and priorities in a way that the situation appears as providing negative outcomes when the other gets zero (i.e., at level z), and as exceeding other's outcomes when these are positive (i.e., at level x). Indeed, in all experiments about half of the participants in the competitive other condition displayed this pattern. Given that the other pursues a competitive goal and seeks to maximize relative advantage, the "rational" choice in the situation described by the participant would be to opt for level $\mathrm{x}$ because this supposedly gives the other 0 and the participant some negative outcome; all other options in the situation described by the participant would provide the decision maker with less than the participant, and thus move the decision maker away rather than towards his or her competitive goal. In other words, with a cooperative other people are honest and describe the situation accurately. With a competitive other people engage in rather sophisticated forms of strategic misrepresentation in which other's competitive goal and his or her most likely course of action is taken into account when (misre)presenting information about the task structure.

\section{The Information Provision Game}

The contributions to theory discussed above largely derive from a newly developed 
Information Provision Game. The game was modeled after the dictator game (Camerer \& Thaler, 1995, Van Dijk \& Vermunt, 2000) and resembles the social interaction situation where one party has to decide whether to provide the other with information about one's preferences and priorities. In the Information Provision Game, the participant's own outcomes depend on a decision made by their counterpart. For each of the decision options the counterpart faces, the participant has full information about the payoffs to both oneself and the counterpart. The counterpart, in contrast, is believed to be informed only about his or her own payoffs, and to have no information about the consequences of his or her choice to the outcomes of the participant. Participants are given the possibility to provide information about the consequences the other's decision would have for the participants' outcomes. By providing accurate or inaccurate information, participants can make some options appear more or less attractive and thus try to steer the other's decision.

The experimental task allowed us to look at the provision of information in close detail, learning about the amount of accurate and inaccurate information presented, and about the direction of deceit. This is, we believe, an important advance over earlier studies on lying and deception that were able to code only whether lying or deception occurred or not. Two questions require an answer. First, the reader may wonder whether findings obtained with this new game generalize to other settings. We believe they do, because the findings obtained in Experiment 3 were replicated in Experiment 4, which used a more conventional transaction decision setting used in previous research on lying and deception (see e.g., Schweitzer \& Croson, 1999). Moreover, the results are highly consistent with those obtained in studies using face-to-face negotiation games (e.g., Murnighan et al., 1999; O’Connor \& Carnevale, 1997). Second, the reader may feel the situation is set up in such a way that participants could easily guess the hypothesis and try to conform to the experimenter's expectations. Although we cannot rule out the possibility that demand characteristics explain some of the results, it is 
unlikely that participants could accurately anticipate the over-assimilation effect found in Experiments 3 and 4. Equally unlikely, it seems, is that participants guessed our hypothesis about the direction of deceit, which was confirmed in Experiments 1 to 3. Thus, the more interesting and important results obtained by means of the Information Provision Game (a) are difficult to explain in terms of demand characteristics, and (b) generalize to other settings.

This being said, it should be noted that some features of the Information Provision Game might have facilitated lying and deception. The setting ruled out negative long-term effects of lying (cf., Boles et al., 2000), participants did not have to fear that others may detect their lies by noticing a telltale incongruous facial expression (Drolet \& Morris, 2000). Moreover, participants could have seen their lack of decision power as a justification for lying (Deutsch, 2000). Obviously, these features may affect the overall base rate of lying and deception but not the specific effects of experimental manipulations. The fact that we replicated the key findings of Experiments 1 and 3 with a more traditional methodology in Experiment 4 suggests that the effects of the experimental manipulations are valid and reliable. Moreover, the features just noted can be easily altered, for example to study lying and deception as a function of visual access, decision power, concern for long-term relationships, or concern with reputation.

\section{Summary and Conclusions}

Most research on the social psychology of lying and deception has been devoted to understanding the human ability to convincingly deceive others (e.g., Vrij et al., 2001b) or to detect lying and deception by others (see DePaulo et al, 2003). To ascertain when and why individuals provide accurate or inaccurate information about their preferences and priorities in social decision situations, we developed the Information Provision Game, which allows one to simultaneously study (a) the amount of information people provide, (b) the accuracy or inaccuracy of the information people provide, and (c) how people represent or misrepresent 
their preferences and priorities. Results showed that individuals are less honest and engage in more deception when their counterpart is believed to be competitive rather than cooperative, and that this effect is stronger for individuals with a pro-social rather than a selfish orientation. Second, greed and fear both predict being honest, and greed but not fear predicts being deceitful. Finally, individuals facing a competitive other engage in sophisticated forms of strategic misrepresentation that may direct competitive others to do exactly the opposite of what their goal prescribes them to do--to hurt him or herself, and to help the participant get great outcomes. 


\section{References}

Bashore, T. R., \& Rapp, P. E. (1993). Are there alternatives to traditional polygraph procedures? Psychological Bulletin, 113, 3-22.

Ben-Yoav, O., \& Pruitt. D. G. (1984). Resistance to yielding and the expectation of cooperative future interaction in negotiation. Journal of Experimental Social Psychology, 20, 323-335.

Boles, T. L., Croson, R. T. A., \& Murnighan, J. K. (2000). Deception and retribution in repeated ultimatum bargaining. Organizational Behavior and Human Decision Processes, 83, 235-259.

Bruins, J. J., Liebrand, W. B., \& Wilke, H. A. M. (1989). About the salience of fear and greed in social dilemmas. European Journal of Social Psychology, 19, 155-161.

Burnham, T., McCabe, K., \& Smith, V. L. (2000). Friend-or-foe intentionality priming in an extensive form trust game. Journal of Economic Behavior and Organization, 43, 5773.

Camerer, C., \& Thaler, R. H. (1995). Anomalies: Ultimatums, dictators, and manners. Journal of Economic Perspectives, 9, 209-219.

Carlsmith, K. M., Darley, J. M., \& Robinson, P. H. (2002). Why do we punish? Deterrence and just deserts as motives for punishment. Journal of Personality and Social Psychology, 83, 284-299.

Carnevale, P. J., \& Probst, T. M. (1998). Social values and social conflict in creative problem solving and categorization. Journal of Personality and Social Psychology, 74, 13001309.

Carnevale, P. J., \& Pruitt, D. G. (1992). Negotiation and mediation. Annual Review of Psychology, 43, 531-582.

Coombs, C. H. (1973). A reparameterization of the prisoner's dilemma game. Behavioral 
Science, 18, 424-428.

Cosmides, L., \& Tooby, J. (1992). Cognitive adaptations for social exchange. In J. H. Barkow, L. Cosmides, \& J. Tooby (Eds.), The adapted mind: Evolutionary psychology and the generation of culture (pp. 163-228). Oxford, UK: Oxford University Press.

De Dreu, C. K. W., Koole, S., \& Steinel, W. (2000). Unfixing the fixed pie: A motivated information processing approach to integrative negotiation. Journal of Personality and Social Psychology, 79, 975-987.

De Dreu, C. K. W., \& Van Kleef, G. A. (in press). The influence of power on information search, impression formation and demands in negotiation. Journal of Experimental Social Psychology.

De Dreu, C. K. W., \& Van Lange, P. A. M. (1995). The impact of social value orientations on negotiator cognition and behavior. Personality and Social Psychology Bulletin, 21, 1178-1188.

De Dreu, C. K. W., Weingart, L. R., \& Kwon, S. (2000). Influence of social motives in integrative negotiation: A meta-analytic review and test of two theories. Journal of Personality and Social Psychology, 78, 889-905.

Dehue, F. M., McClintock, C. G., \& Liebrand, W. B. (1993). Social value related response latencies: Unobtrusive evidence for individual differences in information processing. European Journal of Social Psychology, 23, 273-293.

DePaulo, B. M. (1992). Nonverbal behavior and self-presentation. Psychological Bulletin, $111,203-243$.

DePaulo, B. M., Lanier, K., \& Davis, T. (1983). Detecting the deceit of the motivated liar. Journal of Personality and Social Psychology, 45, 1096-1103.

DePaulo, B. M., Lindsay, J. J., Malone, B. E., Muhlenbruck, L., Charlton, K., \& Cooper, H. (2003). Cues to deception. Psychological Bulletin, 129, 74-118. 
DePaulo, B. M., Stone, J. I., \& Lassiter, G. D. (1985). Telling ingratiating lies: Effects of target sex and target attractiveness on verbal and nonverbal deceptive success. Journal of Personality and Social Psychology, 48, 1191-1203.

Deutsch, M. (1973). The resolution of conflict. New Haven: Yale University Press.

Deutsch, M. (2000). Justice and conflict. In M. Deutsch \& P. T. Coleman (Eds.), The handbook of conflict resolution: Theory and practice (pp. 41-64). San Francisco: Jossey-Bass.

Drolet, A. L., \& Morris, M. W. (2000). Rapport in conflict resolution: Accounting for how face-to-face contact fosters mutual cooperation in mixed-motive conflicts. Journal of Experimental Social Psychology, 36, 26-50.

Ekman, P., \& Friesen, W. V. (1982). Felt, false, and miserable smiles. Journal of Nonverbal Behavior, 6, 238-258.

Ekman, P., Friesen, W. V., \& O’Sullivan, M. (1988). Smiles when lying. Journal of Personality and Social Psychology, 54, 414-420.

Exline, R. V., Thibaut, J., Hickey, C., \& Gumpert, P. (1970). Visual interaction in relation to Machiavellianism and an unethical act. In R. Christie \& F. Geis (Eds.), Studies in Machiavellianism (pp. 53-75). New York: Academic Press.

Folger, R., \& Skarlicki, D. P. (1998). A popcorn metaphor for employee aggression. In: R. W. Griffin, A. O'Leary-Kelly, \& J. M. Collins (Eds.), Dysfunctional behavior in organizations: Violent and deviant behavior. Monographs in organizational behavior and industrial relations, Vol. 23 (pp. 43-81). Stamford, CT: JAI Press.

Folger, R., \& Skarlicki, D. P. (2001). Fairness as a dependent variable: Why tough times can lead to bad management. In: R. Cropanzano (Ed.), Justice in the workplace: From theory to practice (Vol. 2). Series in applied psychology. (pp. 97-118). Mahwah, NJ: Erlbaum. 
Fry, W. R., Firestone, I. J., \& Williams, D. L. (1983). Negotiation process and outcome of stranger dyads and dating couples: Do lovers lose? Basic and Applied Social Psychology, 4, 1-16.

Iedema, J., \& Poppe, M. (1995). Perceived consensus of one's social value orientation in different populations in public and private circumstances. European Journal of Social Psychology, 25, 497-507.

Kagel, J. H., \& Roth, A. E. (1995). The handbook of experimental economics. Princeton, NJ: Princeton University Press.

Kelley, H. H. (1966). A classroom study of the dilemmas in interpersonal negotiations. In K. Archibald (Ed.), Strategic interaction and conflict (pp. 49-73). Berkeley: University of California.

Kelley, H. H., \& Stahelski, A. J. (1970). Social interaction basis of cooperators' and competitors' beliefs about others. Journal of Personality and Social Psychology, 16, 66-91.

Kelley, H. H., \& Thibaut, J. W. (1978). Interpersonal relations. A theory of interdependence. New York: Wiley-Interscience.

Kenny, D. A., Kashy, D. A., \& Bolger, N. (1998). Data analysis in social psychology. In D. Gilbert, S. Fiske, \& G. Lindzey (Eds.), The handbook of social psychology (Vol. 1, 4th ed., pp. 233-265). Boston: McGraw-Hill.

Komorita, S. S., \& Parks, C. D. (1995). Interpersonal relations: Mixed-motive interaction. Annual Review of Psychology, 46, 183-207.

Kuhlman, D. M., Camac, C., \& Cunha, D. A. (1986). Individual differences in social orientation. In H. A. M. Wilke, D. M. Messick, \& C. G. Rutte (Eds.), Experimental social dilemmas (pp. 151-176). Frankfurt am Main, Germany: Peter Lang.

Kuhlman, D. M., \& Marshello, A. F. (1975). Individual differences in game motivation as 
moderators of preprogrammed strategy effects in prisoner's dilemma. Journal of Personality and Social Psychology, 32, 922-931.

Lewicki, R. J. (1983). Lying and deception: A behavioral model. In M. H. Bazerman \& R. J. Lewicki (Eds.), Negotiating in organizations (pp. 68-90). Beverly Hills, CA: Sage.

Liebrand, W. B. G., \& Van Run, G. (1985). The effects of social motives across two cultures on behavior in social dilemmas. Journal of Experimental Social Psychology, 21, 86102.

Liebrand, W. B. G., Jansen, R. W. T. L., Rijken, V. M., \& Suhre, C. J. M. (1986). Might over morality: Social values and the perception of other players in experimental games. Journal of Experimental Social Psychology, 22, 203-215.

Lindskold, S., \& Han, G. (1988). GRIT as a foundation for integrative bargaining. Personality and Social Psychology Bulletin, 14, 335-345.

Messick, D. M., \& McClintock, C. G. (1968). Motivational basis of choice in experimental games. Journal of Experimental Social Psychology, 4, 1-25.

Murnighan, J. K., Babcock, L., Thompson, L. L., \& Pillutla, M. (1999). The information dilemma in negotiations: Effects of experience, incentives, and integrative potential. International Journal of Conflict Management, 10, 313-339.

O’Connor, K. M., \& Carnevale, P. J. (1997). A nasty but effective negotiation strategy: Misrepresentation of a common-value issue. Personality and Social Psychology Bulletin, 23, 504-515.

O’Hair, H. D., Cody, M. J., \& McLaughlin, M. L. (1981). Prepared lies, spontaneous lies, Machiavellianism, and nonverbal communication. Human Communication Research, 7, 325-339.

Paese, P. W., \& Gilin, D. A. (2000). When an adversary is caught telling the truth: Reciprocal cooperation versus self-interest in distributive bargaining. Personality and Social 
Psychology Bulletin, 26, 79-90.

Parks, C. D., Henager, R. F., \& Scamahorn, S. D. (1996). Trust and reactions to messages of intent in social dilemmas. Journal of Conflict Resolution, 40, 134-151.

Price, M. E., Cosmides, L., \& Tooby, J. (2002). Punitive sentiment as an anti-free rider psychological device. Evolution and Human Behavior, 23, 203-231.

Pruitt, D. G. (1990). Problem solving and cognitive bias in negotiation: A commentary. In B. Sheppard, M. H. Bazerman, \& R. J. Lewicki (Eds.), Research on negotiation in organizations (vol. 2, pp. 117-124). Greenwich, CT: JAI Press.

Pruitt, D. G. (1998). Social conflict. In D. T. Gilbert, S. T. Fiske, \& G. Lindzey (Eds.), The handbook of social psychology: Vol. 2 (4th ed., pp. 470-503). New York: McGrawHill.

Pruitt, D. G., \& Kimmel, M. J. (1977). Twenty years of experimental gaming: Critique, synthesis, and suggestions for the future. Annual Review of Psychology, 28, 363-92.

Rapoport, A., \& Eshed, L. D. (1989). Provision of step-level public goods: Effects of greed and fear of being gypped. Organizational Behavior and Human Decision Processes, 44, 325-344.

Riggio, R. E., \& Friedman, H. S. (1983). Individual differences and cues to deception. Journal of Personality and Social Psychology, 45, 899-915.

Rubin, J. Z., \& Brown, B. (1975). The social psychology of bargaining and negotiation. New York: Academic Press.

Rubin, J. Z., Pruitt, D. G., \& Kim, S. H. (1994). Social conflict: Escalation, stalemate, and settlement (2nd ed.). New York: McGraw-Hill.

Rusbult, C. E., \& Van Lange, P. A. M. (1996). Interdependence processes. In E. T. Higgins \& A. W. Kruglanski (Eds.), Social psychology: Handbook of basic principles (pp. 564596). New York: Guilford Press. 
Rusbult, C. E., \& Van Lange, P. A. M. (2003). Interdependence, interaction and relationships. Annual Review of Psychology, 54, 351-375.

Schelling, T. C. (1960). The strategy of conflict. Cambridge, MA: Harvard University Press.

Schweitzer, M. E., \& Croson, R. (1999). Curtailing deception: The impact of direct questions on lies and omissions. International Journal of Conflict Management, 10, 225-248.

Tenbrunsel, A. E. (1998). Misrepresentation and expectations of misrepresentation in an ethical dilemma: The role of incentives and temptation. Academy of Management Journal, 41, 330-339.

Thompson, L., \& Hrebec, D. (1996). Lose-lose agreements in interdependent decision making. Psychological Bulletin, 120, 396-409.

Triandis, H. C., Carnevale, P. J., Gelfand, M., Robert, C., Wasti, S. A., Probst, T., et al. (2001). Culture and deception in business negotiations: A multilevel analysis. International Journal of Cross Cultural Management, 1, 73-90.

Van Dijk, E., \& Vermunt, R. (2000). Strategy and fairness in social decision making: Sometimes it pays to be powerless. Journal of Experimental Social Psychology, 36, 125.

Van Lange, P. A. M. (1992). Confidence in expectations: A test of the triangle hypothesis. European Journal of Personality, 6, 371-379.

Van Lange, P. A. M. (1999). The pursuit of joint outcomes and equality in outcomes: An integrative model of social value orientation. Journal of Personality and Social Psychology, 77, 337-349.

Van Lange, P. A. M., \& Kuhlman, D. M. (1994). Social value orientations and impressions of partner's honesty and intelligence: A test of the might versus morality effect. Journal of Personality and Social Psychology, 67, 126-141.

Van Lange, P. A. M., Liebrand, W. B., \& Kuhlman, D. M. (1990). Causal attribution of 
choice behavior in three N-person prisoner's dilemmas. Journal of Experimental Social Psychology, 26, 34-48.

Vrij, A. (2000). Detecting lies and deceit: The psychology of lying and the implications for professional practice. Chichester, UK: John Wiley \& Sons.

Vrij, A. (2001). Detecting the liars. Psychologist, 14, 596-598.

Vrij, A., Edward, K., \& Bull, R. (2001). Stereotypical verbal and nonverbal responses while deceiving others. Personality and Social Psychology Bulletin, 27, 899-909.

Yamagishi, T. (1986). The provision of a sanctioning system as a public good. Journal of Personality and Social Psychology, 51, 110-116.

Zuckerman, M., Koestner, R., \& Alton, A. O. (1984). Learning to detect deception. Journal of Personality and Social Psychology, 46, 519-528.

Zuckerman, M., Lipets, M. S., Koivumaki, J. H., \& Rosenthal, R. (1975). Encoding and decoding nonverbal cues of emotion. Journal of Personality and Social Psychology, 32, 1068-1076. 


\begin{abstract}
Author Note
This research was sponsored by a grant of the Royal Netherlands Academy of Sciences awarded to Carsten K. W. De Dreu. We thank Gerben A. van Kleef, Bianca Beersma and Daan van Knippenberg for their comments and suggestions and Robbert Hardenberg, Jeroen Hess, Haita Hesse, Anna Küsters and Thea Wegner for their assistance in collecting the data of Experiment 4.

Correspondence concerning this article should be addressed to Wolfgang Steinel or Carsten K. W. De Dreu, Universiteit van Amsterdam, Department of Psychology, Roetersstraat 15, 1018 WB Amsterdam, The Netherlands. Electronic mail can be sent to w.steinel@uva.nl, or to c.k.w.dedreu@uva.nl
\end{abstract}

Update (July 2004): Wolfgang Steinel is now at Leiden University, P. O. Box 9555, 2300 RB Leiden, The Netherlands. Electronic mail can be sent to wsteinel@ fsw.leidenuniv.nl. 
Table 1

Payoff Schedule used in Experiment 1 (Participants are Player 1)

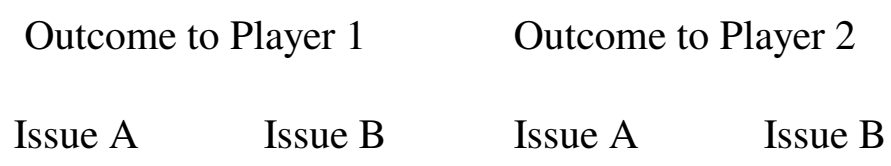

Zero-Sum Task

$\begin{array}{lcccc}\text { Level x } & 0 & 0 & 6 & 2 \\ \text { Level y } & 3 & 1 & 3 & 1 \\ \text { Level z } & 6 & 2 & 0 & 0\end{array}$

Variable-Sum Task

$\begin{array}{llccc}\text { Level x } & 0 & 0 & 2 & 6 \\ \text { Level y } & 3 & 1 & 1 & 3 \\ \text { Level z } & 6 & 2 & 0 & 0\end{array}$

Incomplete Information Task

$\begin{array}{lll}\text { Level } \mathrm{x} & 0 & 0 \\ \text { Level y } & 3 & 1 \\ \text { Level z } & 6 & 2\end{array}$

Note. Participants (player 1) were told that their (fake) player 2 did not receive information about the player 1's outcomes, and only received information about the own (player 2) outcomes. 
Table 2

Amount of Accurate and Inaccurate Information as a Function of Other's Motivation; Experiment 1

\author{
Other's Motivation \\ Cooperative Competitive Unknown
}

\begin{tabular}{llll}
\hline Accurate Information & $3.23_{\mathrm{a}}$ & $0.84_{\mathrm{c}}$ & $2.25_{\mathrm{b}}$ \\
& $(2.36)$ & $(1.23)$ & $(2.31)$ \\
Inaccurate Information & $2.08_{\mathrm{a}}$ & $4.26_{\mathrm{b}}$ & $2.63_{\mathrm{a}}$ \\
& $(2.44)$ & $(1.89)$ & $(2.39)$ \\
Total Information & $5.31_{\mathrm{a}}$ & $5.10_{\mathrm{a}}$ & $4.38_{\mathrm{a}}$ \\
& $(1.33)$ & $(1.94)$ & $(1.71)$ \\
\hline
\end{tabular}

Note. a,b,c Means within one row not sharing the same subscript differ at $p<.05$. Standard deviations in parentheses 
Table 3

Presented Value of Issues A and B, broken down for Other's Motivation; Experiment 1

Issue $\mathrm{A} \quad$ Issue $\mathrm{B} \quad$ paired-sample $t(\mathrm{df}) \quad p$

$\begin{array}{lllll}\text { Other's Motivation } & & & \\ \text { Cooperative } & 2.35(2.98) & 1.55(2.98) & 3.29(52) & <.005 \\ \text { Competitive } & 2.19(2.39) & 2.67(2.30) & -1.73(39) & <.10 \\ \text { Unknown } & 2.51(1.62) & 1.88(2.16) & 1.77(49) & <.10\end{array}$

Note. Numbers in parentheses in the first and the second column are standard deviations. 
Table 4

Means, Standard Deviations, and Correlations of the Main Dependent Variables in Experiment 2

$\begin{array}{lllllll}M & S D & 2 & 3 & 4 & 5 & 6\end{array}$

$\begin{array}{lccccccc}\text { 1. Honesty } & 2.02 & 1.11 & -.20^{\dagger} & -.22^{\dagger} & -.01 & .37^{* *} & -.38^{* *} \\ \text { 2. Fear of Exploitation } & 3.60 & 1.29 & .19 & .38^{* *} & -.35^{* *} .17 & \\ \text { 3. Greed } & 3.96 & 1.30 & & .04 & -.47^{* * *} & .45^{* * *} \\ \text { 4. Punitive Sentiment } & 2.81 & 1.38 & & & -.25^{*} & .18 \\ \text { 5. Accurate Information } & 1.07 & 1.54 & & & & -.74^{* * *} \\ \text { 6. Inaccurate Information } & 4.01 & 1.98 & & & & \end{array}$

Note. ${ }^{\dagger} p<.10 * p<.05 . * * p<.01$ (two-tailed). 


\section{Table 5}

Amount of Accurate and Inaccurate Information as a Function of Experimental Condition;

Experiment 2

Other's Decision is Consequential to

Other (only) Self (only) Both Self and Other

\begin{tabular}{lccc}
\hline Accurate Information & $1.70_{\mathrm{a}}$ & $1.08_{\mathrm{b}}$ & $0.32_{\mathrm{c}}$ \\
& $(1.87)$ & $(1.49)$ & $(0.58)$ \\
Inaccurate Information & $3.39_{\mathrm{a}}$ & $4.04_{\mathrm{b}}$ & $5.05_{\mathrm{c}}$ \\
& $(2.13)$ & $(2.03)$ & $(1.31)$
\end{tabular}

Note. a,b Means within one row not sharing the same subscript differ at $p<.05$.

Standard deviations in parentheses 
Table 6

Amount of Accurate and Inaccurate Information as a Function of Social Value Orientation and Other's Motivation; Experiment 3

Social Value Orientation

Pro-social

Selfish

\begin{tabular}{lllllll} 
Other's Motivation & Cooperative & Competitive & Unknown & \multicolumn{2}{c}{ Cooperative } & Competitive Unknown \\
\hline Accurate Information & $3.90_{\mathrm{a}}$ & $0.50_{\mathrm{d}}$ & $1.82_{\mathrm{bc}}$ & $2.44_{\mathrm{b}}$ & $1.11_{\mathrm{c}}$ & $1.95_{\mathrm{bc}}$ \\
& $(2.34)$ & $(1.10)$ & $(2.02)$ & $(2.06)$ & $(1.09)$ & $(1.96)$ \\
Inaccurate Information & $1.67_{\mathrm{d}}$ & $4.63_{\mathrm{a}}$ & $3.59_{\mathrm{abc}}$ & $2.89_{\mathrm{c}}$ & $4.22_{\mathrm{ab}}$ & $3.10_{\mathrm{bc}}$ \\
& $(2.31)$ & $(1.75)$ & $(2.15)$ & $(2.14)$ & $(1.45)$ & $(2.22)$ \\
\hline
\end{tabular}

Note. a,b,c,d Means within one row not sharing the same subscript differ at $p<.05$.

Standard deviations in parentheses 
Table 7

Amount of Accurate and Inaccurate Information as a Function of Social Value Orientation and Other's Motivation; Experiment 4

Social Value Orientation

Pro-social

Selfish

\begin{tabular}{ccccccc} 
Other's Motivation & Cooperative & Competitive & Unknown & \multicolumn{2}{c}{ Cooperative } & Competitive Unknown \\
\hline Accurate Information & $4.02_{\mathrm{d}}$ & $2.11_{\mathrm{a}}$ & $3.50_{\mathrm{cd}}$ & $3.44_{\mathrm{cd}}$ & $2.74_{\mathrm{b}}$ & $3.11_{\mathrm{bc}}$ \\
& $(0.89)$ & $(0.90)$ & $(0.85)$ & $(0.97)$ & $(0.71)$ & $(1.02)$ \\
Inaccurate Information & $2.02_{\mathrm{a}}$ & $3.23_{\mathrm{c}}$ & $1.88_{\mathrm{a}}$ & $2.02_{\mathrm{a}}$ & $2.64_{\mathrm{b}}$ & $2.59_{\mathrm{b}}$ \\
& $(0.49)$ & $(0.93)$ & $(0.71)$ & $(0.63)$ & $(0.92)$ & $(0.86)$ \\
$n$ & 11 & 11 & 17 & 31 & 31 & 35
\end{tabular}

Note. $\quad$ a,b,c,d Means within one row not sharing the same subscript differ at $p<.05$. 
Figure 1a. The Computer Screen Participants Saw when Providing Information
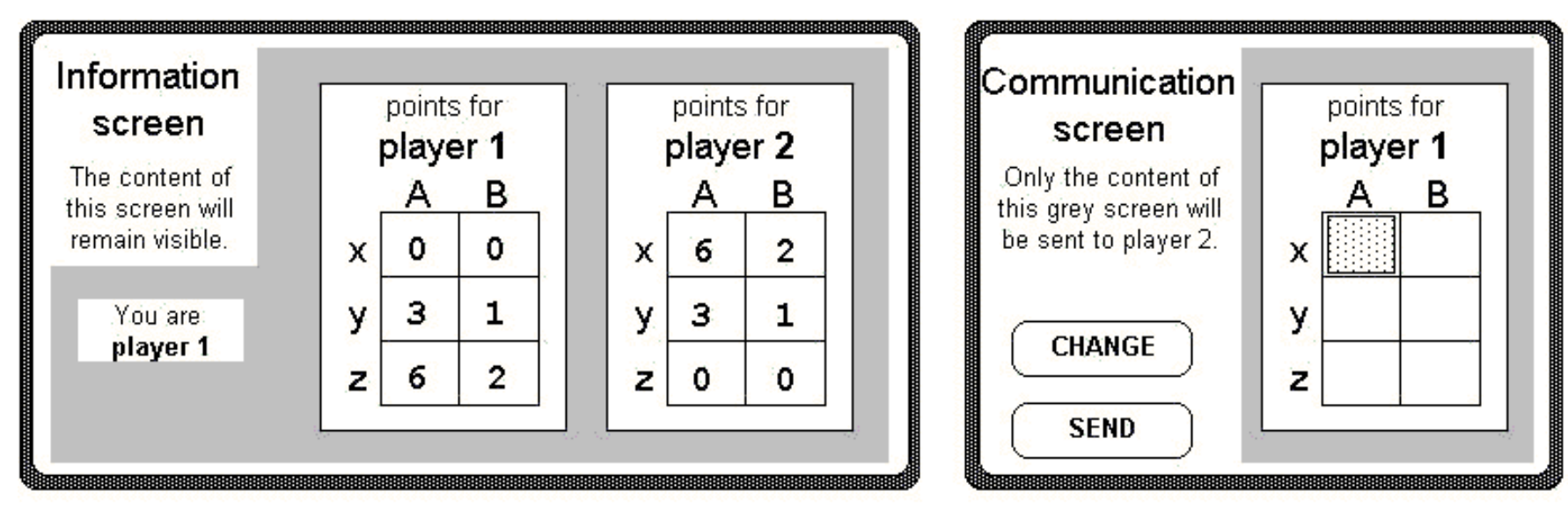

\section{Issue A:}

What information do you send to the other? How many point do you get in cell $\underline{\underline{x A}}$ ?

(Click on the number of your choice. Later, you can still change your choice.)

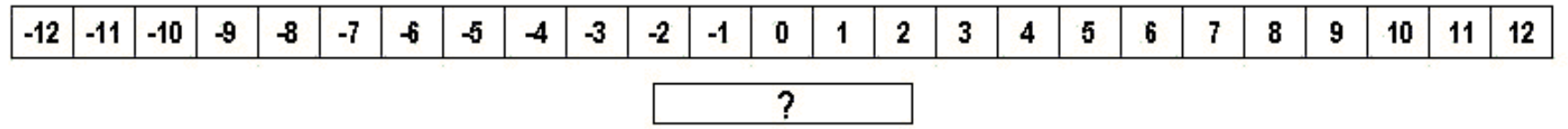

Note. This is the version as shown in Expt. 2, Expt. 3, and in the zero-sum task condition of Expt. 1. Translated from Dutch. Once a participant entered a number (or question mark) in the xA cell of the Communication Screen, a new question prompted the participant to enter a number in cell yA, and so on until all cells were filled. Only then could the "send" function be used. 
Figure 1b. Hypothetical Patterns of Information given to a Cooperative (Left Panel) or Competitive (Right Panel) Other.
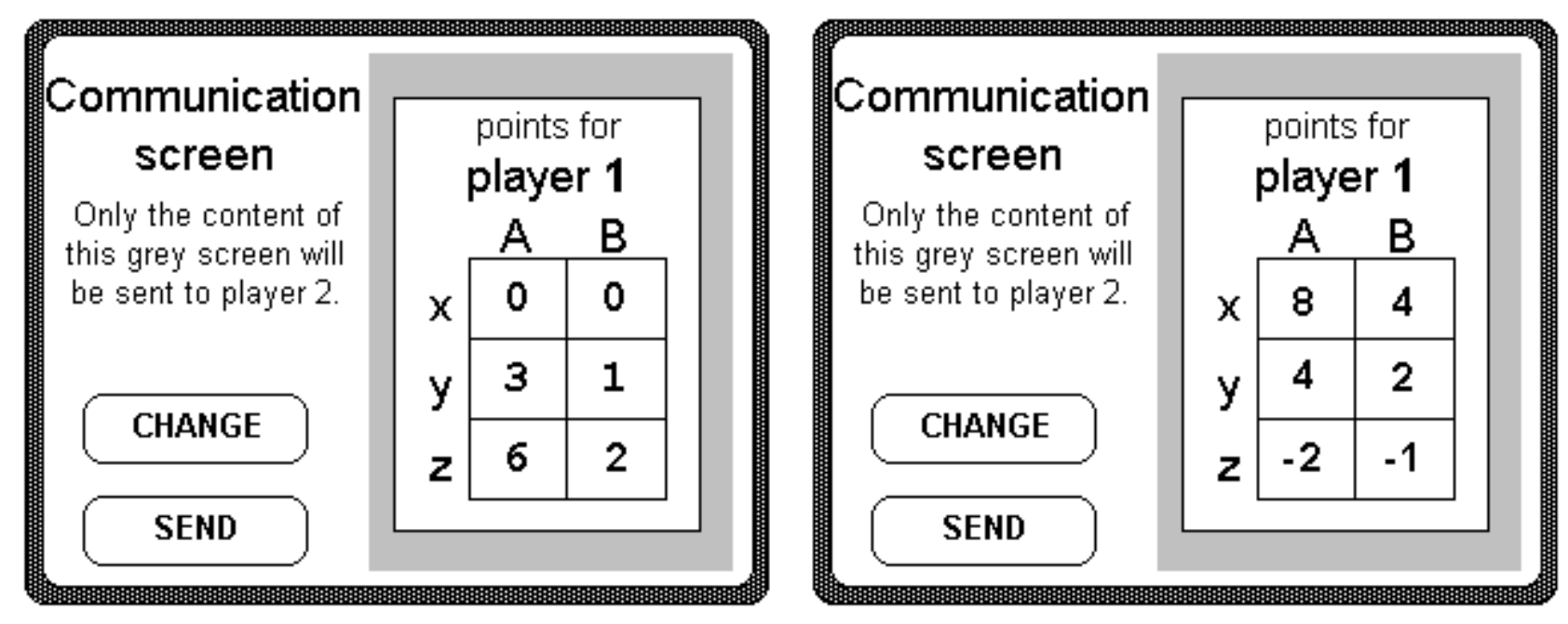

Note. The hypothetical patterns actually resemble what was found for the "direction of deceit" measures taken in Expt. 1 and 3 (see also Figure 2). 
Figure 2. Information About the Value of each Level as a Function of Other's Motivation; Experiment 1

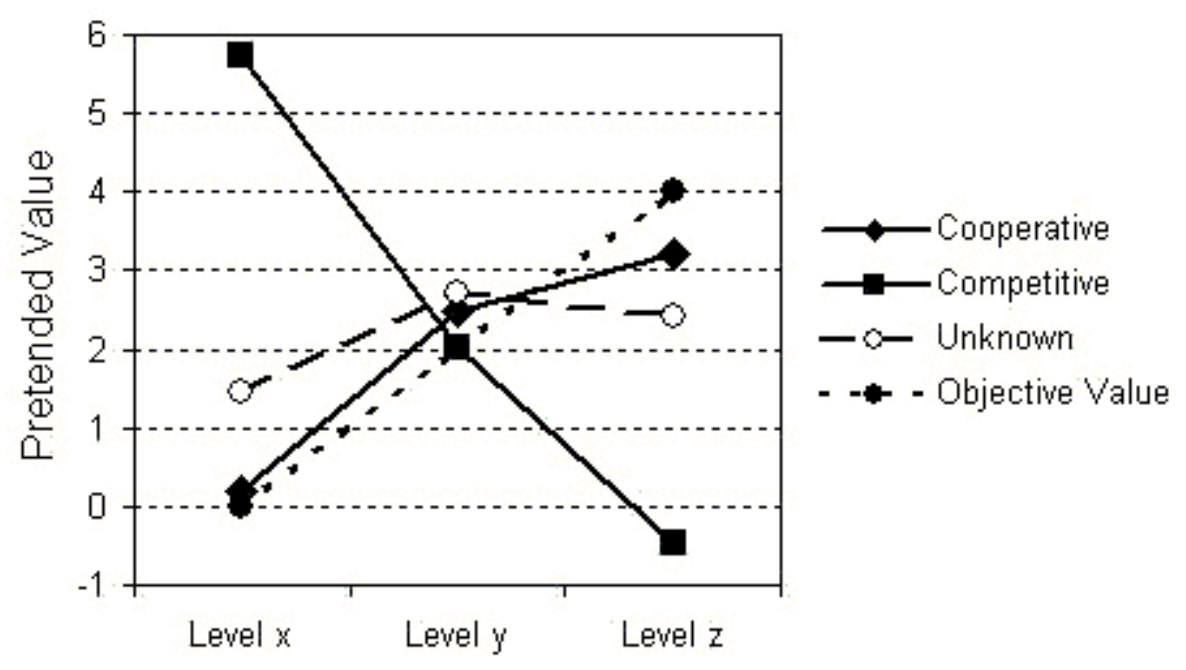

